ENVIRONMENTAL RESTORATION PROGRAM
Decontamination and Decommissioning. Surveillance and Maintenance Report for FY 1991 
This report has been reproduced directly from the best available copy.

Available to DOE and DOE contractors from the Office of Scientific and Technical Information, P.O. Box 62, Oak Ridge, TN 37831; prices available from 615-576-8401, FTS 626-8401.

Available to the public from the National Technical Information Service, U.S. Department of Commerce, 5285 Port Royal Rd., Springfield, VA 22161. 


\section{Decontamination and Decommissioning Surveillance and Maintenance Report for FY 1991}

Decontamination and Decommissioning Program

P.O. Box 2003

Oak Ridge, Tennessee 37831-7298

Date Issued-December 1991

Prepared for

U.S. Department of Finergy

Office of Environmental Restoration and Waste Management

under budget and reporting code EW 20

\section{MARTIN MARIETTA ENERGY SYSTEMS, INC.}

managing the

Oak Ridge National Laboratory

Oak Ridge K-25 Site
Oak Ridge Y-12 Plant

Paducah Gaseous Diffusion Plant

under contract DE-AC05-84OR21400

and the

Portsmouth Gaseous Diffusion Plant

under contract DE-AC05-76OR00001

for the

U.S. DEPARTMENT OF ENERGY

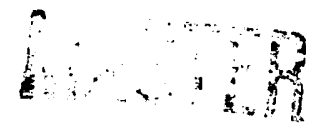




\section{CONTENTS}

ACRONYMS $\ldots \ldots \ldots \ldots \ldots \ldots \ldots \ldots \ldots \ldots \ldots \ldots \ldots \ldots \ldots \ldots \ldots$

ACKNOWLEDGMENTS $\ldots \ldots \ldots \ldots \ldots \ldots \ldots \ldots \ldots \ldots \ldots$ vii

EXECUTTVE SUMMARY $\ldots \ldots \ldots \ldots \ldots \ldots \ldots \ldots \ldots \ldots \ldots \ldots \ldots$ ix

1. INTRODUCTION $\ldots \ldots \ldots \ldots \ldots \ldots \ldots \ldots \ldots \ldots \ldots \ldots \ldots \ldots \ldots \ldots$

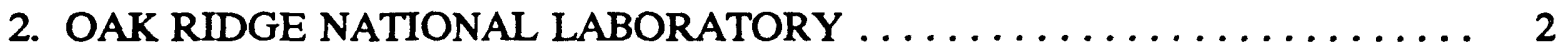

2.1 SURVEILLANCE AND MAINTENANCE PLANNING ......... 2

2.2 ROUTINE SURVEILLANCE AND MAINTENANCE $\ldots \ldots \ldots \ldots \ldots \ldots .4$

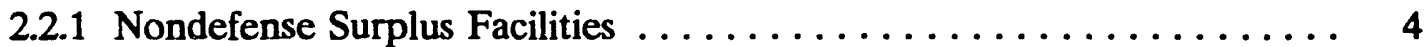

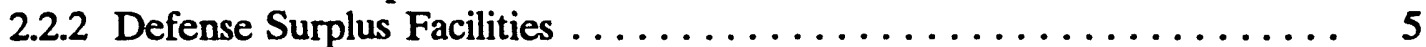

2.2.3 Surplus Contaminated Facilities Program $\ldots \ldots \ldots \ldots \ldots \ldots \ldots$

2.3 SPECIAL MAINTENANCE PROJECTS $\ldots \ldots \ldots \ldots \ldots \ldots \ldots \ldots \ldots$

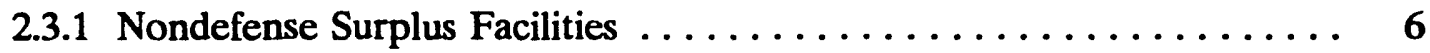

2.3.2 Defense Surplus Facilities .................... 6

2.3.3 Surplus Contaminated Facilities Program $\ldots \ldots \ldots \ldots \ldots \ldots$

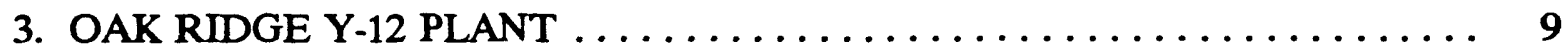

3.1 SURVEILLANCE AND MAINTENANCE PLANNING .......... 9

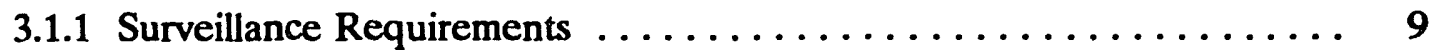

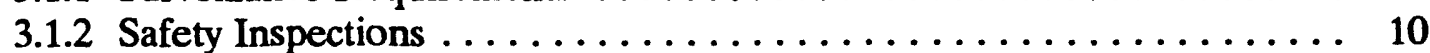

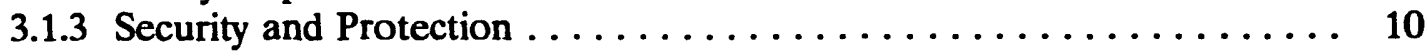

3.1.4 Maintenance Requirements ................... 11

3.2 ROUTINE SURVEILLANCE AND MAINTENANCE $\ldots \ldots \ldots \ldots \ldots \ldots 11$

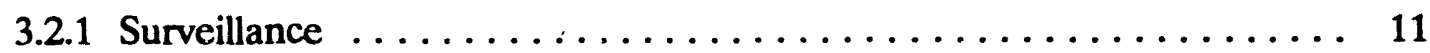

3.2 .2 Maintenance ............................ 11

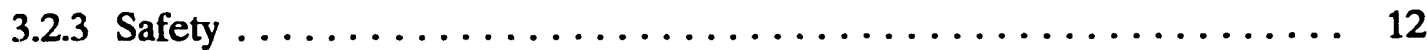

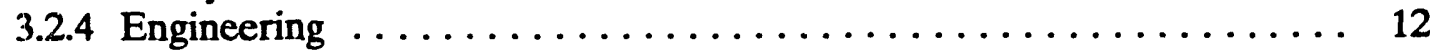

3.3 SPECIAL MAINTENANCE PROJECTS $\ldots \ldots \ldots \ldots \ldots \ldots \ldots \ldots \ldots$

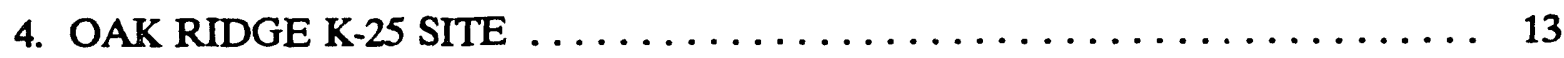

4.1 HAZARDOUS MATERIALS MANAGEMENT FOR HEALTH

AND SAFETY (ASBESTOS) $\ldots \ldots \ldots \ldots \ldots \ldots \ldots \ldots \ldots \ldots \ldots$

4.2 HAZARDOUS MATERIALS MANAGEMENT

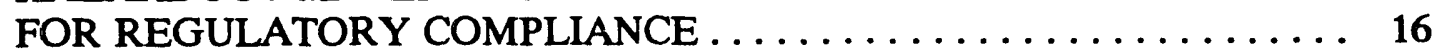

4.2.1 Process Bearing Grade Lubricating Oils $\ldots \ldots \ldots \ldots \ldots \ldots \ldots \ldots$

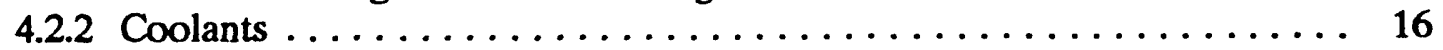

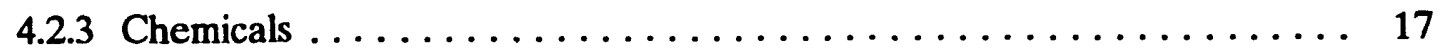

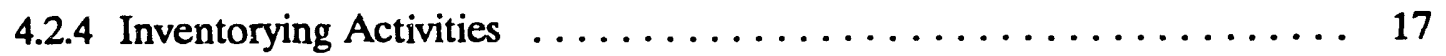

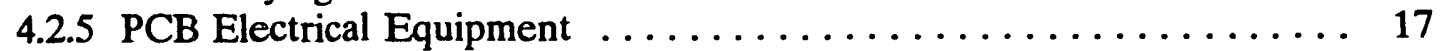

4.3 POLYCHLORINATED BIPHENYL VENTILATION GASKET SPILL

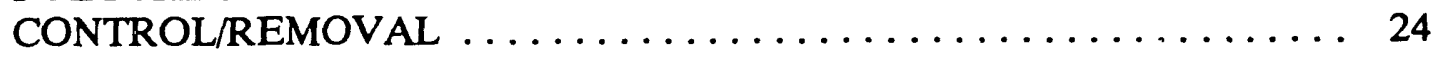


4.4 RADIOLOGICAL CONTAMINATION CONTROL $\ldots \ldots \ldots \ldots \ldots \ldots \ldots$

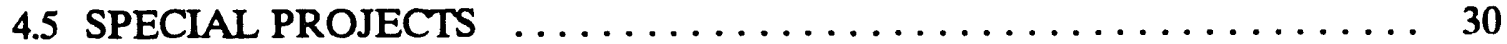

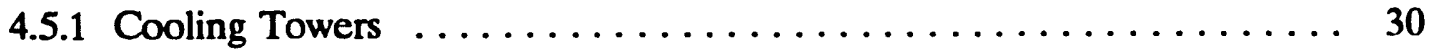

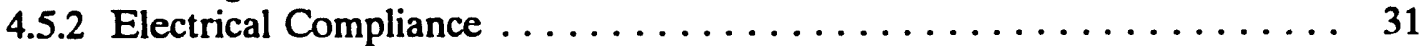

4.5.3 Uranium Deposit Removal . . . . . . . . . . . . . . . 31

4.6 FACILITY SURVEILLANCE AND MAINTENANCE $\ldots \ldots \ldots \ldots \ldots \ldots \ldots$

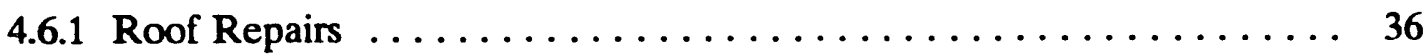

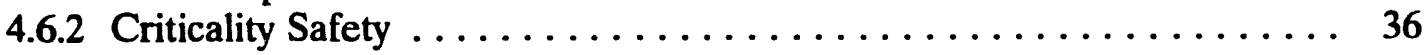

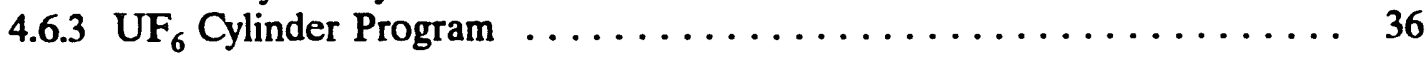

5. $\mathrm{K}-25$ CENTRIFUGE $\ldots \ldots \ldots \ldots \ldots \ldots \ldots \ldots \ldots \ldots \ldots \ldots \ldots$

5.1 SURVEILLANCE AND MAINTENANCE $\ldots \ldots \ldots \ldots \ldots \ldots \ldots \ldots \ldots$

5.2 HAZARDOUS CENTRIFUGE EQUIPMENT AND

MATERIALS STORAGE AND DISPOSAL $\ldots \ldots \ldots \ldots \ldots \ldots \ldots \ldots$

Appendix. SURVEILLANCE ACTIVITY SUPPORTING INFORMATION

FOR THE K-25 SITE D\&D PROGRAM 


\section{ACRONYMS}

$\begin{array}{ll}\text { ACM } & \text { asbestos-containing materials } \\ \text { ADMIS } & \text { Alpha 4 decommissioning management information system } \\ \text { AHERA } & \text { Asbestos Hazardous Emergency Response Act } \\ \text { CERCLA } & \text { Comprehensive Environmental Response, Compensation, and Liability Act } \\ \text { CX } & \text { categorical exclusion } \\ \text { D\&D } & \text { Decontamination and Decommissioning } \\ \text { DOE } & \text { U.S. Department of Energy } \\ \text { DOE-OR } & \text { Department of Energy Oak Ridge Field Office } \\ \text { FFCA } & \text { Federal Facilities Compliance Agreement } \\ \text { HEPA } & \text { high-efficiency particulate air } \\ \text { HRE } & \text { Homogeneous Reactor Experiment } \\ \text { HLRAF } & \text { High-Level Radiation Analytical Facility } \\ \text { MSRE } & \text { Molten Salt Reactor Experiment } \\ \text { NEPA } & \text { National Environmental Policy Act } \\ \text { NMC\&A } & \text { nuclear materials control and accountability } \\ \text { ORNL } & \text { Oak Ridge National Laboratory } \\ \text { OSHA } & \text { Occupational Safety and Health Act } \\ \text { PCB } & \text { polychlorinated biphenyl } \\ \text { QA } & \text { quality assurance } \\ \text { RCRA } & \text { Resource Conservation and Recovery Act } \\ \text { S\&M } & \text { surveillance and maintenance } \\ \text { SCFP } & \text { Surplus Contaminated Facilities Program } \\ \text { TDEC } & \text { Tennessee Department of Environment and Conservation } \\ \text { TSCA } & \text { Toxic Substances Control Act } \\ \text { TVA } & \text { Tennessee Valley Authority } \\ & \end{array}$




\section{ACKNOWLEDGMENTS}

As the compiler of this surveillance and maintenance report for FY 1991, I acknowledge the contributions of key Decontamination and Decommissioning Program staff members, without whose cooperative efforts this project would not have been possible.

\section{Oak Ridge National Laboratory}

T. W. Burwinkle

T. R. Cannon

M. K. Ford

L. Holder, Jr.

Oak Ridge Y-12 Plant

O. K. Clotfelter

Oak Ridge K-25 Site

R. L. Faulkner

D. L. Smith

\section{$K-25$ Centrifuge}

H. O. Wooten

I would also like to thank Dr. Russel Hirst, professor of technical writing in the Department of English at The University of Tennessee, for his editorial contributions. Dr. Hirst was working with the Publications Division, Martin Marietta Energy Systems, Inc., during a semester sabbatical.

David B. Gunter 


\section{EXECUTTVE SUMMARY}

The Martin Marietta Energy Systems, Inc., Central Decontamination and Decommissioning (D\&D) Program Office manages six individual D\&D programs: the Oak Ridge K-25 Site D\&D Program; the K-25 Site Gas Centrifuge Enrichment Facilities D\&D Program; the Oak Ridge National Laboratory (ORNL) D\&D Program; the Oak Ridge Y-12 Plant D\&D Program; and the D\&D programs at the Paducah, Kentucky, and Portsmouth, Ohio, gaseous diffusion plants. As managing contractor, we coordinate and integrate our management of these programs through the Department of Energy Oak Ridge Field Office (DOE-OR) Environmental Restoration Division. The facilities currently included in our D\&D Program are varied, including mercury-contaminated equipment and structures, hot cells, experimental reactors, and uranium enrichment equipment and structures.

The D\&D Program has three distinct phases: (1) surveillance and maintenance (S\&M); (2) decontamination and removal of hazardous materials and equipment (which DOE Headquarters in Washington, D.C., calls Phase I of remediation); and (3) decommissioning and ultimate disposal, regulatory compliance monitoring, and property transfer (which DOE Headquarters calls Phase II of remediation).

A large part of D\&D is devoted to S\&M at each of the sites. Our S\&M activities, which are performed on facilities awaiting decommissioning, are designed to minimize potential hazards to human health and the environment by

- Ensuring adequate containment of residual radioactive and hazardous materials and

- Providing physical safety and security controls to minimize potential hazards to on-site personnel and the general public.

Typically, we classify maintenance activities as either routine or special (major repairs). Routine maintenance includes such activities as painting, cleaning, vegetation control, minor structural repairs, filter changes, and building system(s) checks. Special maintenance includes Occupational Safety and Health Act facility upgrades, roof repairs, and equipment overhaul.

Surveillance activities include inspections, radiological measurements, reporting, records maintenance, and security (as required) for controlling and monitoring access to facilities.

This report summarizes our FY 1991 S\&M activities for the Tennessee plant sites, which include the K-25 Site, the Gas Centrifuge facilities, ORNL, and the Y-12 Plant.

\section{Oak Ridge National Labonatory D\&D}

The ORNL D\&D Program continued S\&M activities during FY 1991, including facility acceptance planning, asbestos hazards surveys, and S\&M for the defense and nondefense surplus facilities and for the Surplus Contaminated Facilities Program. Special maintenance projects included environmental reviews and preparation of documentation for asbestos abatement at the Oak Ridge Graphite Reactor and the Molten Salt Reactor Experiment. 
The environmental document for National Environmental Policy Act compliance for the waste evaporator facility roof repair was approved, and installation should be complete by FY 1992.

Filters were changed in the High-Level Chemical Development Laboratory. We also removed stored chemicals and hazardous materials as part of the cleanup of the Decontamination Facility.

Other activities included a screening and classification process for facility hazards.

\section{Y-12 Plant D\&D}

At the Y-12 Plant surveillance activities continued to record mercury-in-air readings, sump water volume discharges, and emergency protection equipment and maintenance was performed to eliminate steam and water leaks and housekeeping to collect elemental mercury from floor sweepings.

In addition, Engineering has been evaluating the building systems such as floor structure, electrical systems, and piping systems in preparation for D\&D planning. Estimates to disassemble and remove process equipment were completed in FY 1991.

\section{$K-25$ Site DED}

Many projects are under way at the K-25 Site. In the asbestos removal program, the engineering design for the removal of $\sim 9$ miles of thermal insulation was completed. Also, a projert to remove 3400 lin $\mathrm{ft}$ of deteriorating asbestos-containing insulation was completed. In the hazardous materials management program, $\sim 19,000$ gal of waste and radioactively contaminated oil was sent to the DOE Toxic Substances Control Act (TSCA) Incinerator; 116,000 gal of fluids highly concentrated with polychlorinated biphenyls (PCBs) was removed and incinerated; 18,500 gal of mineral oil containing low concentrations of PCBs was incinerated by the DOE TSCA Incinerator; and 52 oil circuit breakers, $\sim 100$ insulators, 129 disconnect switches from the K-31 and K-33 switchyards were transferred to the Tennessee Valley Authority (TVA), saving the expense of disposal for DOE and the cost of purchase for TVA.

The PCB gasket removal project began in FY 1991 to address the Federal Facilities Compliance Agreement. Feasibility studies and cost estimates were completed, and a technical proposal package was prepared.

Special projects addressed the cooling towers, electrical compliance, and uranium deposit removal. Other activities included cleanup and sampling of 68 PCB leaks, weekly facility walkdowns, $\mathrm{UF}_{6}$ cylinder inspections, asbestos survey, 30-day inspection of $\sim 3500$ PCB waste drums, and facility cleanup and management of low-level radioactive material. Repairs to the roof in $\mathbf{2 0}$ areas were completed. 


\section{K-25 Centrifuge}

For the Centrifuge Program, daily, weekly, and monthly building system inspections and facility walk-throughs for routine surveillance, emergency protection, and fire protection systems were performed. The underground diesel fuel storage tanks at Building K-1220 were removed. A consolidation of materials and equipment resulted in an approximate reduction of $10,000 \mathrm{ft}^{2}$ of storage requirements. 


\section{INTRODUCTION}

The Martin Marietta Energy Systems, Inc., Central Decontamination and Decommissioning (D\&D) Program Office manages six individual D\&D programs: the Oak Ridge K-25 Site D\&D Program; the K-25 Site Gas Centrifuge Enrichment Facilities D\&D Program; the Oak Ridge National Laboratory (ORNL) D\&D Program; the Oak Ridge Y-12 Plant D\&D Program; and the D\&D programs at the Paducah, Kentucky, and Portsmouth, Ohio, gaseous diffusion plants. As managing contractor, we coordinate and integrate our management of these programs through the Department of Energy Oak Ridge Field Office (DOE-OR) Environmental Restoration Division. The facilities currently included in our D\&D Program are varied, including mercury-contaminated equipment and structures, hot cells, experimental reactors, and uranium enrichment equipment and structures.

Our D\&D Program has three distinct phases: (1) surveillance and maintenance (S\&M); (2) decontamination and removal of hazardous materials and equipment (which DOE Headquarters in Washington, D.C., calls Phase I of remediation); and (3) decommissioning and ultimate disposal, regulatory compliance monitoring, and property transfer (which DOE Headquarters calls Phase II of remediation).

A large part of D\&D is devoted to S\&M at each of the sites. Our S\&M activities, which are performed on facilities awaiting decommissioning, are designed to minimize potential hazards to human health and the environment by

- Ensuring adequate containment of residual radioactive and hazardous materials and

- Providing physical safety and security controls to minimize potential hazards to on-site personnel and the general public.

Typically, we classify maintenance activities as either routine or special (major repairs). Routine maintenance includes such activities as painting, cleaning, vegetation control, minor structural repairs, filter changes, and building system(s) checks. Special maintenance includes Occupational Safety and Health Act (OSHA) facility upgrades, roof repairs, and equipment overhaul.

Surveillance activities include inspections, radiological measurements, reporting, records maintenance, and security (as required) for controlling and monitoring access to facilities.

This report summarizes our FY 1991 S\&M activities for the Tennessee plant sites, beginning with ORNL. 


\section{OAK RIDGE NATIONAL LABORATORY}

S\&M is an integral part of the D\&D Program at ORNL. S\&M must ensure that the current inventory of inactive, contaminated sites and facilities are adequately contained and controlled. We meet these objectives through a structured program of routine S\&M as well as through interim corrective maintenance when site surveillance identifies the need for it. These activities ensure that we adequately control sites before decontaminating facilities that will be reused or before starting final decommissioning. Program activities fall into three principal areas:

- S\&M planning: program-level planning and coordination of surveillance activities conducted by divisions responsible for specific facilities, including routine reporting.

- Routine S\&M: scheduled site inspections, sampling and analysis of contaminated pathways, and periodic maintenance as a result of inspections and monitoring.

- Special maintenance: correction of serious site deficiencies beyond the scope of routine maintenance.

The ORNL D\&D Program provides this support for facilities contaminated with radioactivity or hazardous chemical waste and no longer supported by active programs. Facilities included in the program formerly supported research, technology development, or waste management activities; these facilities vary greatly in size and physical configuration.

Facilities included in the ORNL D\&D Program had been used in developing research technology, producing and processing isotopes, and managing wastes. These facilities were formerly supported through the Surplus Contaminated Facilities Program (SCFP), Defense D\&D Program, and the Energy Research KG-funded, ORNL-originated SCFP. This chapter overviews the S\&M planning, routine S\&M, and special maintenance project activities that have occurred in the ORNL D\&D Program during FY 1991.

\section{SURVEILLANCE AND MAINTENANCE PLANNING}

\section{Facility Acceptance Planning}

The S\&M planning subtask establishes and maintains organization and system in our program. During the planning subtask, we not only fulfill routine reporting requirements but also integrate all of the other S\&M subtasks into a safe, responsive, and cost-effective effort to meet program objectives. Many of our objectives for specific facilities, of course, are dependent on directives we get from the DOE Headquarters D\&D Program office in Washington, D.C. DOE Headquarters reviews facilities to determine if they are eligible for acceptance into the EM-40 D\&D Program. In addition to the 27 facilities already accepted into the EM-40 D\&D Program, the following three facilities appear to meet the criteria for acceptance:

- Decontamination Facility (Building 7819)

- Off-Gas Filter House (Building 3121)

- Isotope Production Filter House (Building 3110, including the Isotope Ductwork) 
We have applied to DOE Heacuquarters for acceptance of these three facilities.

DOE Headquarters has notified ORNL that nine facilities, because they currently do not meet $D \& D$ acceptance criteria, cannot be accepted into the program. Because of this, funding will be provided only through FY 1992 for the following facilities:

- 3503, Storage Pad

- 3019-B, High-Level Radiation Analytical Facility

- 3029, Cobalt-60 Storage Garden

- 3028, Strontium-90 Power Generators

- 9201-2, 86-Inch Cyclotron

- 9204-3, Plutonium Processing Facility

- 9204-3, Curium Handling Glovebox

- 9204-1. Contaminated Attic

- 9204-1, East End Basement

However, one of the facilities, the 3503 Storage Pad, may be funded beyond FY 1992 if DOE Headquarters accepts a recent applicatio- containing information which may qualify it for the program.

\section{DOE Tiger Team Assessment}

Preparations were made in late FY 1990 to provide tours of surplus facilities to personnel contracted by DOE to assess these facilities in terms of environmental, safety, and health issues. These planned tours, part of an ORNL-wide assessment, took place over a period of 2 months. Experts in the areas of process and management control, with particular emphasis on concerns related to OSHA, were present for the inspections. They made no specific findings for any facilities in the D\&D Program.

\section{Facility Asbestos Abatement}

Also in FY 1990, Radian Corporation surveyed surplus facilities for potential hazards related to asbestos. These surveys enabled the ORNL Industrial Hygiene Department to determine the future need for abatement activities at inese facilities. We received and assessed these results and developed a schedule for FY 1991 abatement for areas needing immediate attention. National Environmental Príicy Act (NEPA) documentation was submitted to DOE Headquarters for a categori:al exclusion (CX), and approval is still pending.

\section{Facility Hazard Screening}

We have segregated and grouped facilities in the D\&D Program for hazard screening, grouping the facilities according to the magnitude of their hazards in order to determine the need for and extent of follow-on safety documentation.

The hazard screening process places facilities into one of four initial hazard classifications. We use the initial classification in determining whether further safety analysis is required. At this stage in the screening process, we have proposed all surplus facilities in the D\&D S\&M Program as low-hazard facilities, with the exception of the Molten Salt Reactor Experiment (MSRE), which we have proposed as a moderate-hazard facility. 


\section{Surveillance Planning}

We have submitted NEPA compliance documents for (1) repackaging of zinc bromide solution stored at the MSRE, (2) sampling and analysis of water at the Homogeneous Reactor Experiment (HRE) storage pool and the 3002 filter house canal plus addition of integrators to the process water makeup, (3) waste evaporator roof repair, and (4) OSHA compliance upgrades at the HRE and the Low-Intensity Test Reactor.

\section{ROUTINE SURVEILLANCE AND MAINTENANCE}

\section{Nondefense Surplus Facilities}

\section{Molten Salt Reactor Experiment}

DOE Tiger Teams visited the MSRE in October 1990. Tiger Team personnel included representatives from radiation protection, criticality, groundwater monitoring, and fire protection, as well as a process chemist interested in process corrosion at MSRE associated with design of the drain tanks system. The teams' observations centered on OSHA compliance and postings at the facility. Responding to inquiries by Tiger Team groups, we added to the site several signs indicating that MSRE is inactive and awaiting decommissioning.

We changed the east bank of cell-ventilation filters at MSRE and tested them for dioctyl phthalate. Testing showed that the bank could continue service. Also, finding a leaky bearing on the east fan unit, we replaced the unit and put it on standby.

We have calibrated instrumentation associated with the reactor and drain tank cells which is linked to tiue Waste Operations Control Center, checking all differential transmitters, local gages, and associated linkages to establish new set points for parameters that have changed since reactor shutdown.

We have prepared for an upcoming radiological monitoring activity that will coincide with the annual reheat and drain tank cell leak test at MSRE. In order to ascertain background radiation for potential shielding, we surveyed radiological conditions in the north electric service area where the monitoring will likely be staged. The tests are scheduled for FY 1992.

We also completed a task to clean up the facility. The cleanup focused on priorities established by heath and safety needs/deficiencies. We sent $-150 \mathrm{ft}^{3}$ of solid low-level waste to tumulus for disposal, salvaged many items for reuse by ORNL, inspected and retagged electrical equipment, and had Industrial Hygiene post additional warning placards for asbestos.

\section{Shielded Transfer Tanks}

Materials were delivered to erect a removable awning over the Shielded Transfer Tanks being stored at the Decontamination Facility, Building 7819, and the four required footings have been poured. Environmental review and documentation for NEPA compliance have been completed and received for the construction of the awning over the tanks. The work is scheduled for early FY 1992. 


\section{Defense Surplus Facilities}

\section{Supplus Reactors}

Members of the DOE Tiger Team visited HRE, the Low-Intensity Test Reactor, and the Oak Ridge Graphite Reactor. They emphasized OSHA compliance, groundwater monitoring, and air emissions at the facilities.

We developed an action plan to address findings from NUS Corporation assessing surplus reactor facilities with respect to OSHA violations. The action plan is prioritized according to environmental, safety, and health issues that have direct bearing on S\&M personnel performing work at the facility. This action plan also incorporates several current internal safety inspections in order to prioritize all activities of a similar nature and therefore better integrate all upcoming safety projects into one work package. Environmental review and documentation for NEPA compliance is pending a CX determination.

We subcontracted to Afftrex, Ltd., radiological surveillance of the HRE. The survey, which they finished this year, updates an earlier (mid-1970s) report published by ORNL personnel while providing survey results compatible with current guidelines and limits. Afftrex took beta-gamma and alpha direct measurements for radiation and contamination for all accessible portions of HRE. A report of the findings is due in early FY 1992.

Also, Radian Corporation assessed asbestos conditions at the HRE. They took more than 70 samples from over 20 contiguous areas within the facility. Their report is pending.

Environmental documentation for NEPA compliance was completed and received for proceeding with the HRE Storage Pool Inventory. Following the approval, miscellaneous debris located around the pool was surveyed, segregated by radiological methods, and disposed of. We then finished inventorying the storage pool and logging its contents for future decontamination plans. Results will be published in early FY 1992.

\section{Old Hydrofracture Facility}

Old Hydrofracture Facility (7852) control-room blower bearings were noisy and in need of service. A greasing in addition to the normal plant-maintenance schedule solved the problem; however, these bearings have exceeded their expected life, and we plan to replace them. Part of the noise was belt squeal, which we fixed by dressing the belts. The bearing housing, bearings, and pulleys also have been received for the pump house blower that is the same age. We plan to install the new parts in early FY 1992.

\subsection{Surplus Contaminated Facilities Program}

We conducted routine S\&M at the SCFP facilities as scheduled; site inspections and radiological surveillance found no major problems at these facilities.

Inspectors checked for asbestos in the top of the hot cells at the High-Level Radiation Analytical Facility (Building 3019-B). This area contains a filter cell bank with asbestos insulation. The filters were removed and the asbestos located, identified, and temporarily isolated. 
We are reassessing S\&M requirements for the High-Level Chemical Development Laboratory (Building 4507) facility to ensure that they adequately address environmental, safety and health, and program requirements. As part of the ORNL-wide effort to update safety documentation for all facilities, we have completed a preliminary hazard screening worksheet for the $\mathbf{3 1 1 0}$ Filter House.

\section{SPECIAL MAINTENANCE PROJECTS}

\subsection{Nondefense Surplus Facilities}

\section{MSRE Zinc Bromide Repackaging}

We received the approved environmental documentation for proceeding with the zinc bromide repackaging and transfer at MSRE. We transferred the solution from the Maintenance Control Room to a diked area in the Diesel Room (Bldg. 7555), transferred it into 30-gal poly-lined drums inside a fabricated diked area, and secured the drums for storage, complete with U.S. Department of Transportation placards and Material Safety Data Sheets available on site.

\section{MSRE asbestos abatement}

Environmental review and documentation were also initiated in February for abatement of asbestos from air-conditioning ducts within the high-bay area of MSRE. We will take further action on this project when our NEPA documents are approved.

\subsection{Defense Surplus Facilities}

\section{Sampling and Analysis and Placement of Integrators for the Homogeneous Reactor Experiment Pool and the 3002 Filter House Canal}

We received the approved environmental review documentation for sampling and analyzing these pools and placing integrators on makeup water lines to the pools. We put new integrators on the process makeup lines and, working with environmental sampling and analysis personnel at ORNL, scheduled an early FY 1992 sampling of both pools.

\section{Waste Evaporator Roof Repair}

We finished the environmental document for NEPA compliance and got approval to install a new roof. Installation is under way; the roof should be finished early in FY 1992. We also gave the exterior of the building a new coat of paint.

\section{Graphite Reactor Asbestas Abatement}

Environmental review and documentation were initiated in March for asbestos abatement at several hazardous areas on process piping in the Oak Ridge Graphite Reactor. We will take further action on the project when DOE approves our NEPA documents. 
OSHA Compliance Upgrades for the Homogeneous Reactor Experiment and the Low-Intensity Test Reactor

Environmental review and documentation were initiated in February 1990 for upgrades to these facilities to comply with OSHA standards for industrial facilities. We will take further action on the project when DOE approves our NEPA documents.

\subsection{Surplus Contaminated Facilities Program}

\section{High-Level Chemical Development Laboratory (Building 4507) Filter Change}

Inadvertent valving of process water wet the roughing and absolute filters in the cell-vent system for the High-Level Chemical Development Laboratory (Building 450?) in FY 1990. The wetted filters were scheduled to be changed in FY 1990 pending approval of NEPA compliance documentation. DOE approved the change in August 1991; we changed the filters, checked the quality of the new filters, and put the filtering system back into operation.

On December 23,1990 , during a period of extremely heavy rain ( $>6$ in. within $30 \mathrm{~h}$ ), flooding in a ventilation duct temporarily cut off ventilation to Building 4507 . We isolated the building and increased surveillance for radioactivity in the areas surrounding the hot cells but found no signs that containment had been lost. Normal drainage cleared the problem on the following day, so after reviewing building drawings, we opened an additional drainage valve Jn December 28, 1990. Since no personnel were exposed, equipment damaged, production lost, or other adverse effects noted, we judged this incident to have no negative impact and reported it as a nonroutine occurrence.

\section{Isotope Production Filter House (Building 3110) Filter Change}

This reporting period has seen no activity on the project to replace the highly contaminated roughing and high-efficiency particulate air (HEPA) filters in the 3110 Filter House. We have prepared a CX from further NEPA documentation; when DOE Headquarters approves the project, we will continue with it.

\section{Decontamination Facility (Building 9419-1) Cleanup}

The objective of this project is to clean up the facility and bring it to a safe shutdown condition by removing stored chemicals and other hazardous materials presently in the building and presenting a risk to continued containment. This project was temporarily delayed awaiting DOE approval of a CX. However, during a recent Resource Conservation and Recovery Act (RCRA) inspection of the facility by the Tennessee Department of Environment and Conservation (TDEC), several chemicals were identified as requiring immediate removal. ORNL Environmental Compliance personnel approved the removal of the chemicals stored in the Decontamination Facility (9419-1) before receiving NEPA approval from DOE Headquarters. All the chemicals were subsequently relocated to an approved storage facility to await disposal. DOE has since approved the CX, and we will resume work after completing an internal environmental assessment and determining outfall locations of facility drain lines. The building has been locked to control access during the delay. 
East End Basement (Building 9204-1) Access Control Improvements

We removed all excess material from the 9204-1 East End Basement before DOE Headquarters interrupted the authorized use of funds for this project.

\section{6-Inch Cyclotron Facility (Building 9201-2) Projects}

There are three special projects associated with the 86-Inch Cyclotron Facility: (1) removing Z-Oil lines, (2) removing sources of contamination and cleaning up, and (3) changing filters. We removed asbestos from the Z-oil lines and Z-oil heaters this year; abatement was necessary before the Z-oil system itself could be removed. DOE Headquarters interrupted work on these projects when they found that the facility did not meet D\&D Program acceptance criteria. However, we expect work to continue in FY 1992 based on current funding guidance.

Interim Decontamination Facility (Building 7819) Equipment Removal and Dispasal

Planning is in progress for continued removal of contaminated material from Building 7819. Most of the remaining material is large machinery associated with the original operation.

High-Level Radiation Analytical Facility (Building 3019-B) Decontamination

Decontamination of the High-Level Radiation Analytical Facility progressed in FY 1991; we removed and disposed of a highly contaminated filter in the off-gas system from Cell 6. We also made progress on decontaminating and removing debris from behind the cells before DOE Headquarters interrupted authorized use of funds, thereby suspending activity. 


\section{OAK RIDGE Y-12 PLANT}

The D\&D program at the Oak Ridge Y-12 Plant is part of the Environmental Restoration and Waste Management Program. This work is funded through the Office of Environmental Restoration and Waste Management and Weapons Operation. Its objective is to enable $\mathrm{Y}-12$ to meet applicable environmental regulations through facility decommissioning activities and site decontamination actions. In support of this objective, the D\&D Program collectively manages sites within $\mathrm{Y}-12$ which are in need of action; prioritizes those areas in terms of health, safety, and environmental concerns; and takes the appropriate level of remedial action. The program supports identifiable facilities that formerly served one or more of the many Y-12 functions. Program activities include (1) S\&M of facilities awaiting decommissioning; (2) planning safe and orderly facility decommissioning; and (3) implementing a program to accomplish facility disposition in a safe, cost effective, and timely manner.

The Y-12 D\&D program is administered by the Program Management Division, with programmatic direction from the Central D\&D Office under the Office of Environmental Restoration and Waste Management. S\&M is one of three primary components of remedial action. The other components include management of current remedial action projects, nearterm planning, and long-range planning.

S\&M functions are carried out by a multidisciplinary team from many different operational, support, and research divisions. However, primary responsibility for conducting S\&M lies with the division under whose control the facility formerly operated or, in some cases, the division responsible for D\&D. The multidisciplinary team will evaluate each facility that falls into the category of D\&D and will recommend assignment of S\&M responsibility based on their evaluation of the contaminated materials involved at the facility. The determination for S\&M responsibility will be made to ensure that all safety requirements are met.

\subsection{SURVEILLANCE AND MAINTENANCE PLANNING}

\subsubsection{Surveillance Requirements}

We routinely survey D\&D facilities to ensure that each site remains in a radiologically safe condition and that hazardous materials are safely contained. Inspectors survey radiological conditions, monitor the operability of any equipment required to maintain safe conditions, check safety-related items, provide site security controls, and inspect structural integrity.

Each D\&D facility must be periodically inspected. The frequency of inspection is determined by the type of facility, the level of containment provided for hazardous or radioactive materials, and the potential for personnel access to the site. The facility supervisor or his designated appointee normally surveys the facility as part of a routine inspection of other operating areas. Surveillance items include the following. 
- Visual inspection of the facility or equipment for structural or system failures, material degradation, liquid leaks, radiation monitor indications, burning odors, and equipment irregularities.

- Routine checks on containment ventilation systems, including pressure drop readings, indicators of building or cell negative pressures, and operability of auxiliary containment systems.

- Observation of liquid levels in sump areas, storage tanks, canals, and storage pools.

- Process equipment operability checks, including air compressors, water pumps, and sump pumps.

- Checks/inspections of argon manifolds, steam systems, manipulators, and other mechanical systems vital to maintaining safe protective storage at specific facilities.

In addition to these operator surveillance activities, the plantwide surveillance program routinely inspects radiation detection instrumentation, building exterior and roof conditions, and overhead cranes; it also tests HEPA filtration systems. These on-site inspections and routine audits meet Y-12 quality assurance requirements.

\subsubsection{Safety Inspections}

Inspectors will continue to routinely examine all D\&D facilities to identify existing and potential hazards to personnel. They will also inspect facilities and safety-related equipment for proper accessibility and operability. Inspections will take place semiannually in accordance with plant practices and procedures. So that they may be as effective and consistent as possible, the inspections will be carried out in conjunction with routine safety inspections for the active facilities in the respective areas and by the same inspection team appointed for this task. Safeiy surveillance will focus on general inspection of building conditions to identify unsafe conditions, unsafe practices, fire hazards, etc. We will refer action items that result from these inspections to facility supervisors for correction, and corrective action or maintenance performed as a result will become part of the S\&M file for the facility. Inspectors may undertake more frequent inspections (weekly, monthly, or quarterly) or testing of emergency equipment as deemed appropriate by the facility supervisor, fire protection personnel, or safety staff personnel.

\subsubsection{Security and Protection}

Because it is a restricted government installation, Y-12 has comprehensive safeguards, security, and protection systems. These systems include exclusion fencing around the main plant complex and around remote facilities, continuously manned guard posts, controlled access to sensitive and hazardous areas, fire alarm and protection systems, a fully equipped and continuously manned fire department, and routine (random) security patrols. Because of this complete and comprehensive network, D\&D sites require few additional security or protective measures. Access to facilities containing potential hazards is further restricted by facility operators who must minimize unnecessary entry of personnel. Controlled access is usually accomplished by keeping abandoned areas in a locked and secured condition, restricting entry, and clearly posting radiation and chemical hazards. 


\subsubsection{Maintenance Requirements}

Maintenance of D\&D facilities falls into two categories: (1) routine or programmed maintenance and (2) special maintenance required for major repairs of structures or equipment. The Maintenance and Utilities Division conducts most program maintenance according to its own routine maintenance schedule or at the request of facility supervisors. While the Y-12 Plant takes care of many of the routine maintenance items (grounds care, exterior painting, and preventative equipment maintenance), D\&D must support other maintenance, major repairs, or improvements directly related to the upkeep of the surplus facility.

\subsection{ROUTINE SURVEILLANCE AND MAINTENANCE}

There is currently only one facility, Alpha 4, accepted into the D\&D Program. In FY 1991, we have surveyed and maintained the Alpha 4 (Building 9201-4) process facility to ensure that it remains in a safe, permanently shutdown condition. Surveillance is needed to ensure that we (1) find fallen or exposed friable asbestos; (2) identify leaks and take appropriate corrective action; (3) clean up mercury leaks and properly store the material to prevent environmental insults; (4) check to see that the criticality alarm, fire alarm, electrical lighting, and other essential electrical equipment are operating properly; (5) provide janitorial and custodial care to ensure that we meet health and safety standards; and (6) maintain calibration on life-safe equipment.

\subsubsection{Surveillance}

Surveillance is a daily function. While keeping abreast of environmental regulations, legislation, and issues, we continue to inspect for structural damage, leaks, hazardous or probable hazardous materials (mercury, in particular); perform various other surveillance activities; and check on safeguards and personnel health care. Specifically, some of our activities in FY 1991 were

- Daily recording of sump water volume discharged to East Fork Popular Creek

- Daily recording of mercury-vapor-in-air readings taken at three locations in each of 20 zones

- Weekly delivery of personnel urine samples to the laboratory to ensure an accurate tracking of personal care of each employee

- Recording of who enters and exits the building

- Input of information as stated in these activities into the Alpha 4 decommissioning management infornation system data base (ADMIS) for a permanent record

\subsection{Maintenance}

Some of our routine maintenance activities were

- Eliminating utility steam leaks, water leaks, and potential leaks 
- Reducing building steam pressure from operational requirements of 150 psig to building heat requirements of $30 \mathrm{psig}$, thus eliminating costly annual inspection requirements of regulating devices

- Eliminating future histoplasmosis threats by blocking pigeons and other birds from entering the building

- Sweeping floors and stairways and stripping elemental mercury from sweepings

\subsection{Safety}

Some of our routine safety activities were

- Updating the fire suppression system and other fire protection, such as keeping fire extinguishing bottles in readiness

- Inspecting for potential fire hazards and for general housekeeping conditions and then documenting them and clearing discrepancies

- Keeping emergency and health protection equipment in ready and available condition

- Training in personal protection against mercury contamination and in other policies and procedures for all mercury workers and any workers who may be performing job tasks for the first time in the Alpha 4 building

\subsubsection{Engineering}

Evaluations, inspections, and analyses by Engineering have been ongoing and will continue throughout D\&D Program activities. These evaluations included

- Evaluating building floor structures

- Inspecting and testing crane lifting devices for update requirements and pendant control

- Identifying electrical components needed to support the facility D\&D activities and marking engineering drawings

- Marking piping drawings to clearly identify services that must remain active to support D\&D activities

- Evaluating cost of removing insulation

- Estimating disassembly cost to remove Colex and support equipment

- Starting research and development studies to determine an acceptable waste decontamination and disposal plan

- Studying methods of roasting mercury-contaminated material

- Drafting an S\&M plan

\subsection{SPECIAL MAINTENANCE PROJECTS}

There were no special maintenance projects for the Alpha 4 facility during FY 1991. 


\section{OAK RIDGE K-25 SITE}

The objective of the Oak Ridge K-25 Site D\&D Program is the ultimate disposition of the gaseous diffusion process buildings and their supporting facilities-including remediation of potential contamination in the soils under the process buildings. As soon as separative work projections indicated that the K-25 Site gaseous diffusion plant, which was already in a standby condition, was no longer needed and that restart was no longer an option, efforts began to place the process facilities into a permanently shutdown, long-term, safe-storage condition to significantly reduce the potential for environmental insult or adverse health and safety effects from the facilities. Also, once the standby period was over, thereby indicating that most of the equipment and chemicals there were no longer needed, all of the materials became surplus. If future uses for these surplus materials are not found, they will become "wastes" as defined by RCRA; the Comprehensive Environmental Response, Compensation, and Liability Act (CERCLA); and the Toxic Substances Control Act (TSCA). Conversion of the facilities from standby to safe-storage condition through Phase I D\&D, which is currently under way, will bring the facilities into compliance with all applicable laws and regulations and, at the same time, reduce the funding required for S\&M of the facilities. The facilities will be maintained in this rondition for an extended period. During Phase II, the decommissioning phase, we must ultimately dispose of the large quantity of equipment that is contaminated internally with uranium, as well as dispose of the buildings and all associated concrete and soil.

\subsection{HAZARDOUS MATERIAIS MANAGEMENT FOR HEALTH AND SAFETY (ASBESTOS)}

This program establishes the hazardous materials management activities to protect on-site personnel from the health and safety risks associated with friable asbestos in the gaseous diffusion facilities. Most of the friable asbestos at the gaseous diffusion facilities is thermal system insulation for pipes and ducts. Since much of the $\sim 21$ miles of friable asbestos is in various states of deterioration, it holds a high potential for personnel exposure, environmental insult, and regulatory violation. This deterioration is caused by age, abrasion, vibration, weather, temperature extremes, humidity, and lack of maintenance. Federal law requires us to remove all (friable and nonfriable) asbestos-containing materials (ACM) from buildings before demolition.

Principal asbestos program activities are

- Asbestos Operations and Maintenance Program: We plan to remove known asbestos from existing gaseous diffusion facilities over an 8-year period. Until it is removed, DOE and K-25 Site policy guidelines require an effective, formulated plan of training, cleaning, work practices, and surveillance to maintain ACM in good condition (Figs. 1 and 2; see also the K-25 Site asbestos walk-through inspection and assessment form in the appendix).

- Engineering design and contract specifications: This portion of the program deals with the project characterization, engineering design, contract specification, and contractor surveillance requirements for the more than 50 contract demolition packages. 


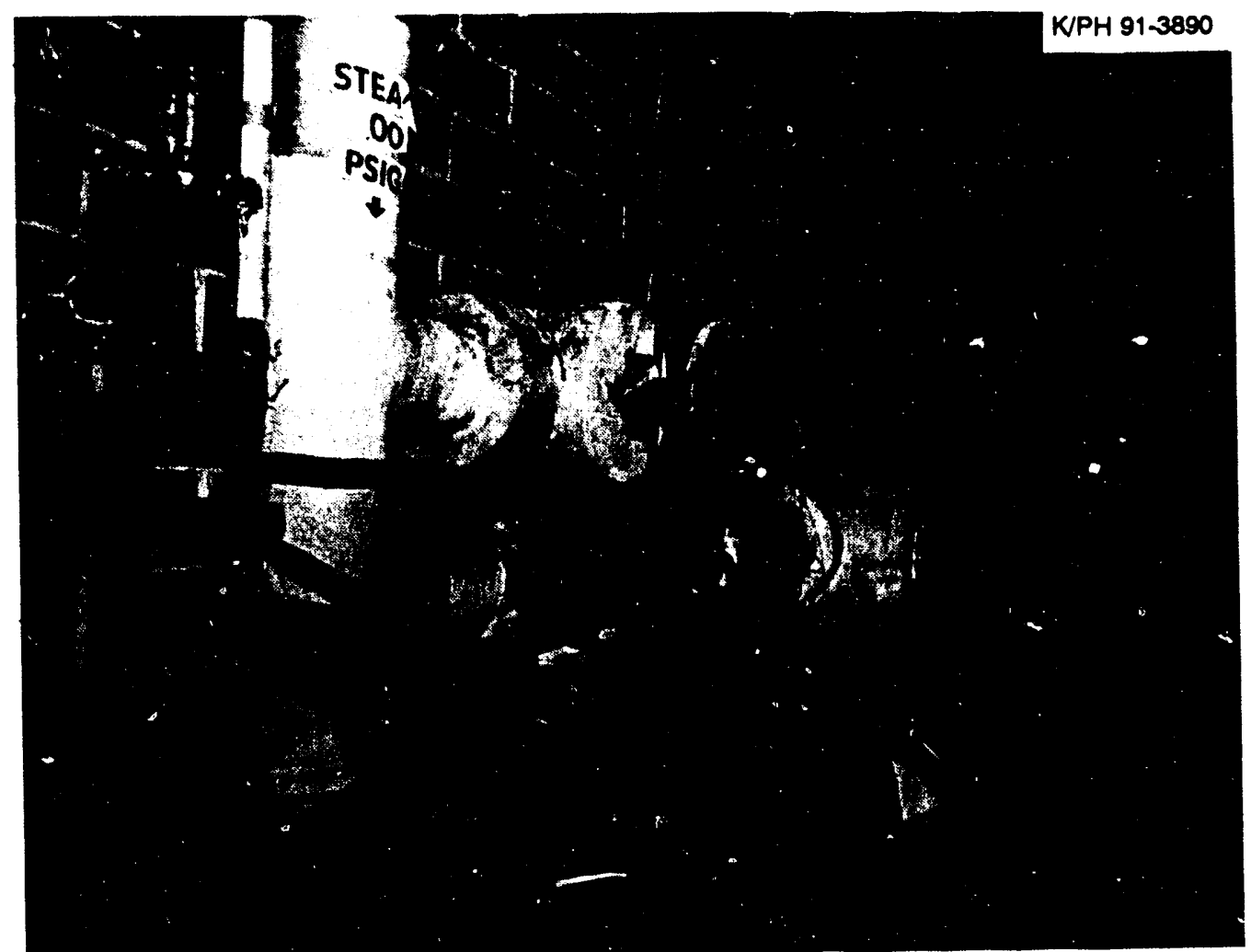

Fig. 1a. Steam station before asbestos removal

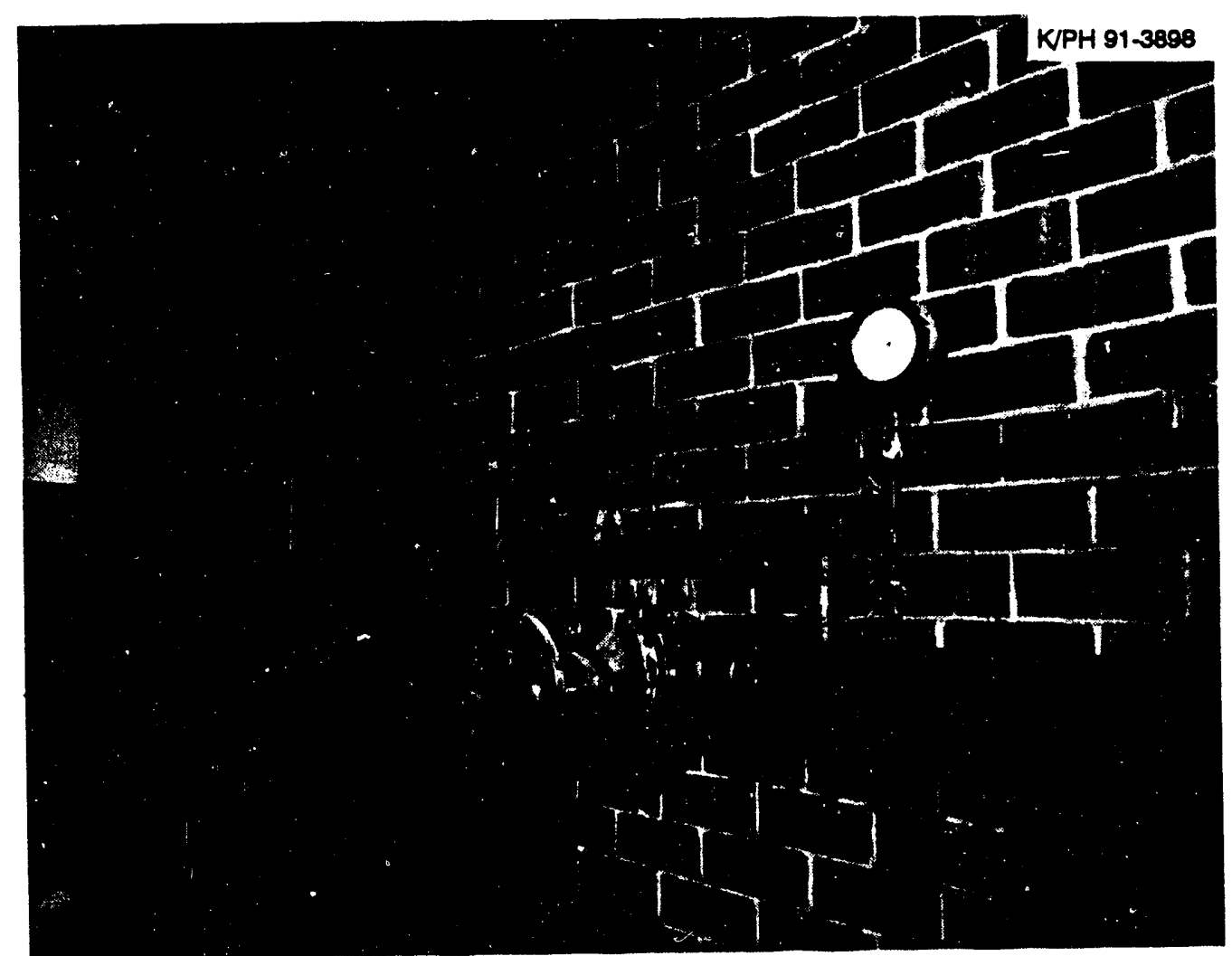

Fig. 1b. Steam station after asbestos removal. 


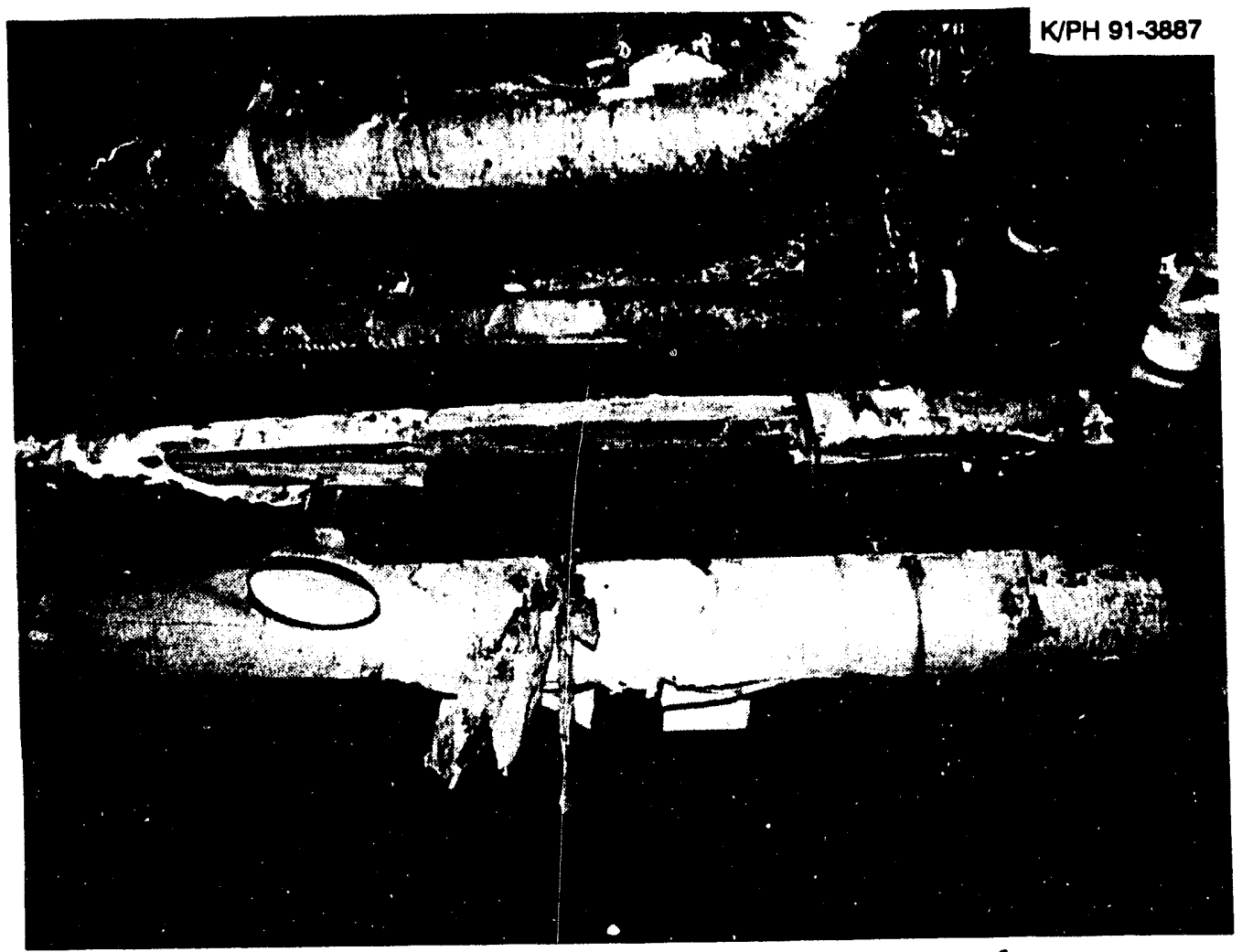

Fig. 2a. Pipe with exposed asbestos before removal

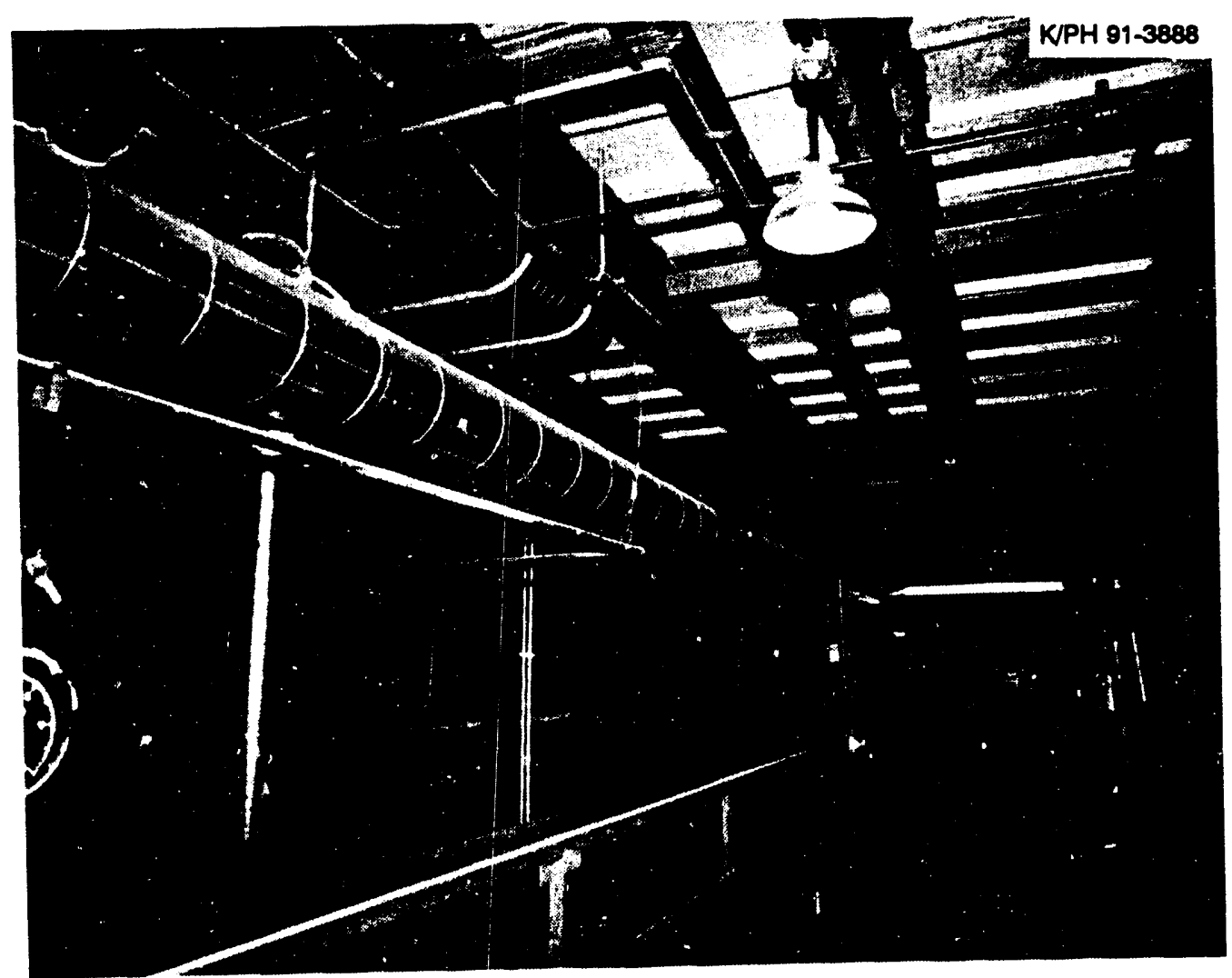

Fig. 2b. Reinsulated steam lines after asbestos removal and maintenance. 
- Asbestos removal by licensed subcontractor: We will use subcontractors licensed by the state of Tennessee for large asbestos removal activities except when security and contamination constraints require us to use DOE prime contractor direct-hire personnel.

During FY 1991, the Asbestos Operations and Maintenance Program hired a manager for the asbestos program, upgraded asbestos worker and supervisor (competent person) training to include new National Emission Standards for Hazardous Air Polluting Substances training requirements in addition to the Asbestos Hazardous Emergency Response Act (AHERA) and OSHA requirements, visually inspected all thermal system insulation in all shutdown facilities, and employed three maintenance craftsmen full time to patch/seal exposed asbestos identified in the visual inspection program.

Engineering design and contract specifications activities included contracting for AHERA-type asbestos inspections in four buildings and completing engineering design for removal of $\sim 9$ miles of thermal system insulation.

During FY 1991, that section of the program using licensed subcontractors to remove asbestos funded two large-scale asbestos removal projects. The first project, removal of 3400 lin $\mathrm{ft}$ of deteriorating thermal system insulation, ran from June 1991 to September 1991. The second project, removal of 2200 lin $\mathrm{ft}$ of insulation and cleaning of $13,000 \mathrm{ft}^{2}$ of contaminated surface area, began in September 1991 and is expected to be completed in early 1992.

\subsection{HAZARDOUS MATERIALS MANAGEMENT FOR REGULATORY COMPLIANCE}

\subsection{Process Bearing Grade Lubricating Oils}

We finished sampling and analysis of the $\sim 100$ tanks that comprise the process lubricating oil system and got the analytical laboratory results in FY 1991. Tests detected uranium in $-30,000$ of the 270,000 total gallons left in reservoirs throughout the shutdown facilities, but there was no PCB concentration over the regulated amount of $50 \mathrm{ppm}$. These results were required to meet a milestone in the proposed TSCA Federal Facilities Compliance Agreement (FFCA), which required sampling and analysis as well as locations and volumes of all reservoirs of oil.

During the past year, we sent $\sim 19,000$ gal of radioactively contaminated oil to the DOE TSCA Incinerator at K-25. DOE's ban on off-site shipments has placed on hold Energy Systems' efforts to market the noncontaminated oil for recycling. This option is still viable if DOE lifts the ban, but if the ban continues, we will explore other options, including burning all the oil in the TSCA incinerator. Additional laboratory analysis to further characterize the oil is under way to facilitate option assessments.

\subsection{Coolants}

We plan to start sampling the C816/B437 process coolants early in 1992. One manufacturer still produces these coolants, so they might still be reused. Coolants will be analyzed for ${ }^{238} \mathrm{U}$ and enriched uranium to assess recycling/reuse alternatives as well as waste disposal methods. 


\section{Chemicals}

We are collecting containers of surplus chemicals that were associated with activities in the operating gaseous diffusion facilities and moving them to a staging area to enhance material control and management. Over 3700 containers have been collected which vary in volume from several ounces to several gallons. We began the consolidation program which has allowed us to consolidate into 17 drums over 930 small containers that were considered waste. This effort, which has already reduced sampling and analysis cost by several hundred thousand dollars, will continue through FY 1992 when the buildings should be considered free of unused chemicals. Furthermore, K-25 Site personnel have reused several hundred items, saving sampling and disposal costs as well as cost avoidances for purchasing new material (see Figs. 3 and 4).

\section{Inventorying Activities}

Inventory activities in FY 1991 focused on the chemicals discussed in Sect. 4.2.3. An extensive data base systern has been developed for managing the material and characterization data generated from inventory activities. Once the process-related fluids and chemicals have been completely inventoned, activities will focus on characterizing equipment with recycle potential.

\section{PCE Electrical Equipment}

In FY 1991, we removed large quantities of PCB-containing materials from the shutdown buildings. We gave highest priority for removal and disposal to fluids containing PCBs. The largest amount of PCBs in the shuidown facilities are contained in 87 transformers and 8 tanks in the K-33 building. These transformers contained $\sim 116,000$ gal of high-concentration PCBs (typically greater than $500,000 \mathrm{ppm}$ ). A bid specification for the disposal of this material was awarded to Environmental Systems Company (Ensco) to drain and dispose of this fluid by incineration at an EPA-approved incinerator. They finished the on-site work in March and the off-site incineration in May. Figures 5, 6, and 7 show the setup for fluid to be drained from the transformer, assisted by a booster pump, and show the containment to prevent any spills or leaks. Figure 8 shows the arrangement for transferring the fluid into a vacuum truck for off-site transportation.

We destroyed another 18,500 gal of mineral oil containing PCBs in the on-site TSCA Incinerator. The majority of this fluid $(\sim 78 \%)$ contained TSCA-regulated amounts of PCBs. The remainder of this fluid contained $\mathrm{PCBs}$, although not regulated amounts $(<50 \mathrm{ppm})$. This material was removed from transformers located in the K-33 and K-33 switchyards during July and August.

TVA requested and was given permission to remove a number of electrical equipment items from the K-33 and K-31 switchyards. This material contained small amounts of PCBs ( $<10 \mathrm{ppm}$ ) that are not regulated under the TSCA regulations. The material transferred to TVA was coordinated by the Power and Utilities Division and included 52 oil circuit breakers containing $\sim 240,000$ gal of mineral oil, an additional 120,000 gal of mineral oil from other electrical equipment items, $\sim 100$ insulators, and 129 disconnect switches. This transfer saved TVA the expense of purchasing this material and saved Energy Systems the expense of disposal. 


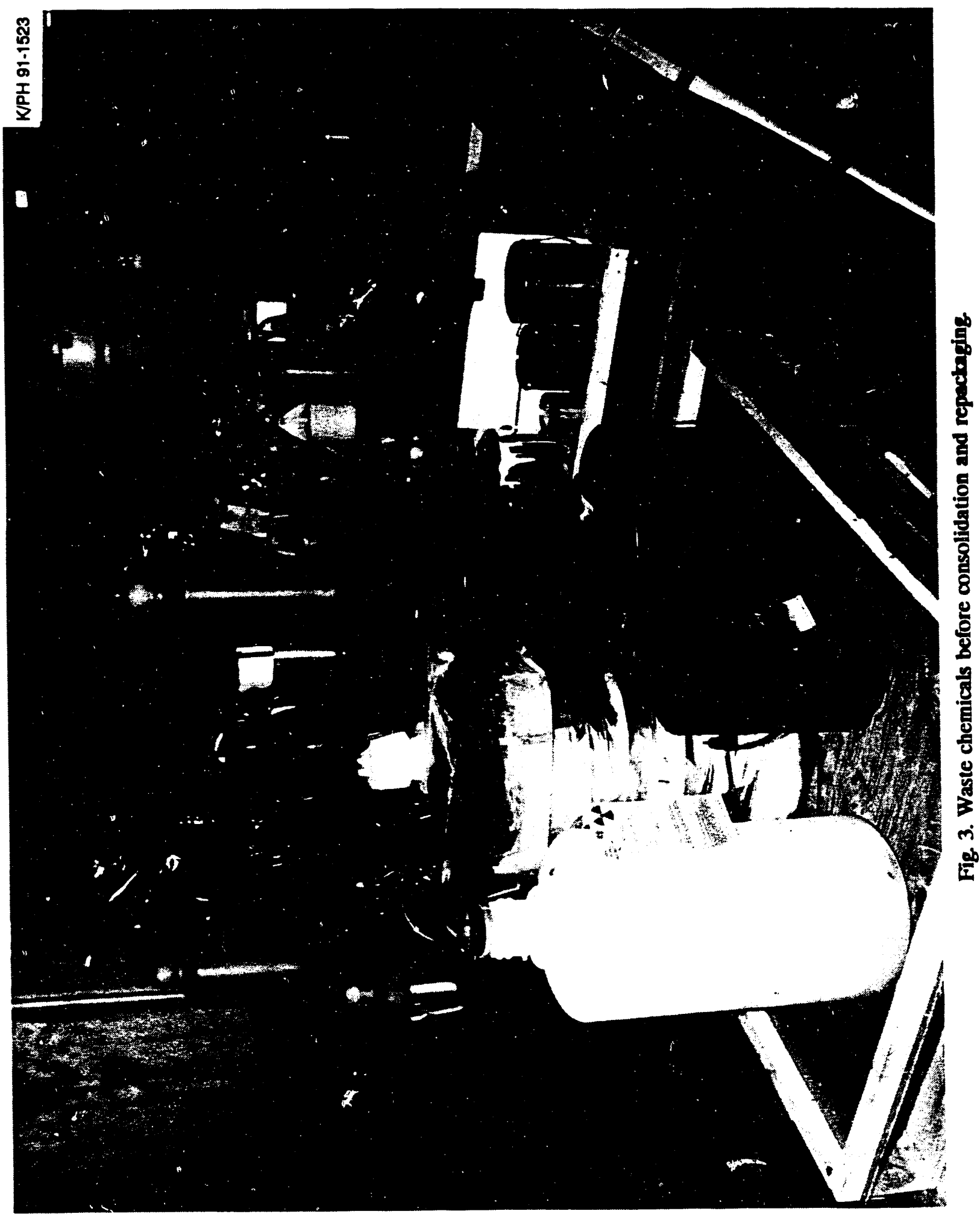




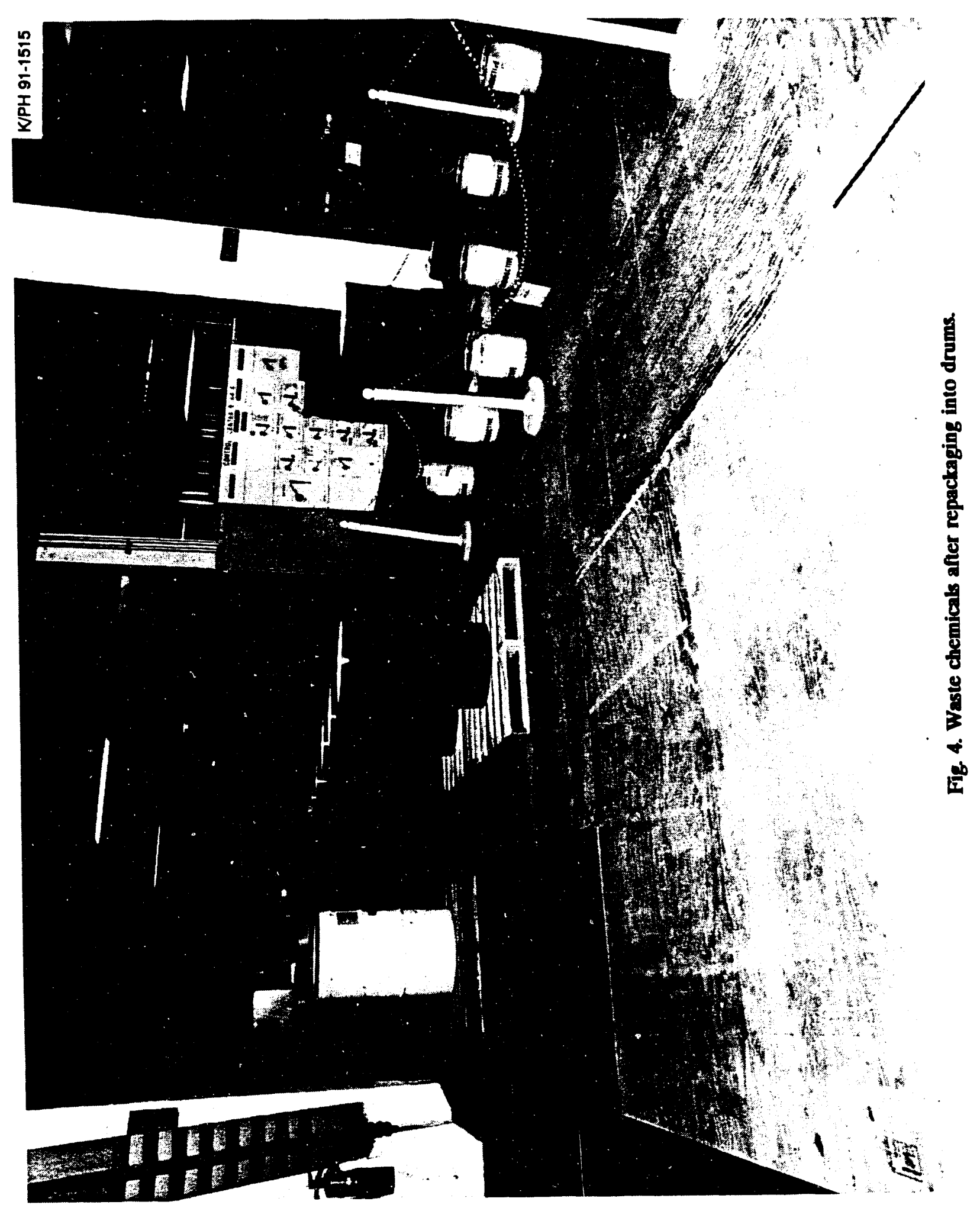




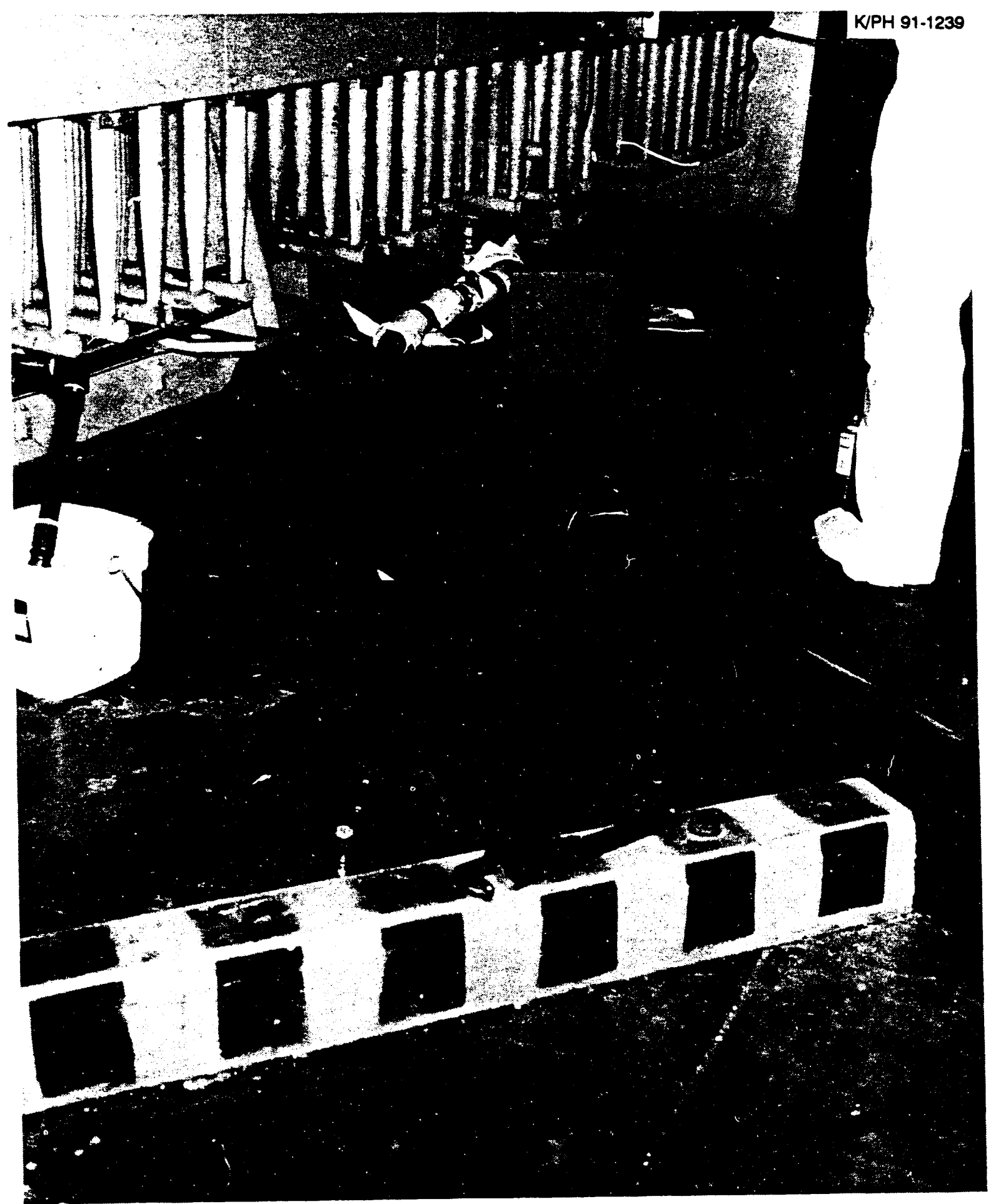

Fig. 5. Fluid flowing from transformer into vacuum line to tanker truck. 


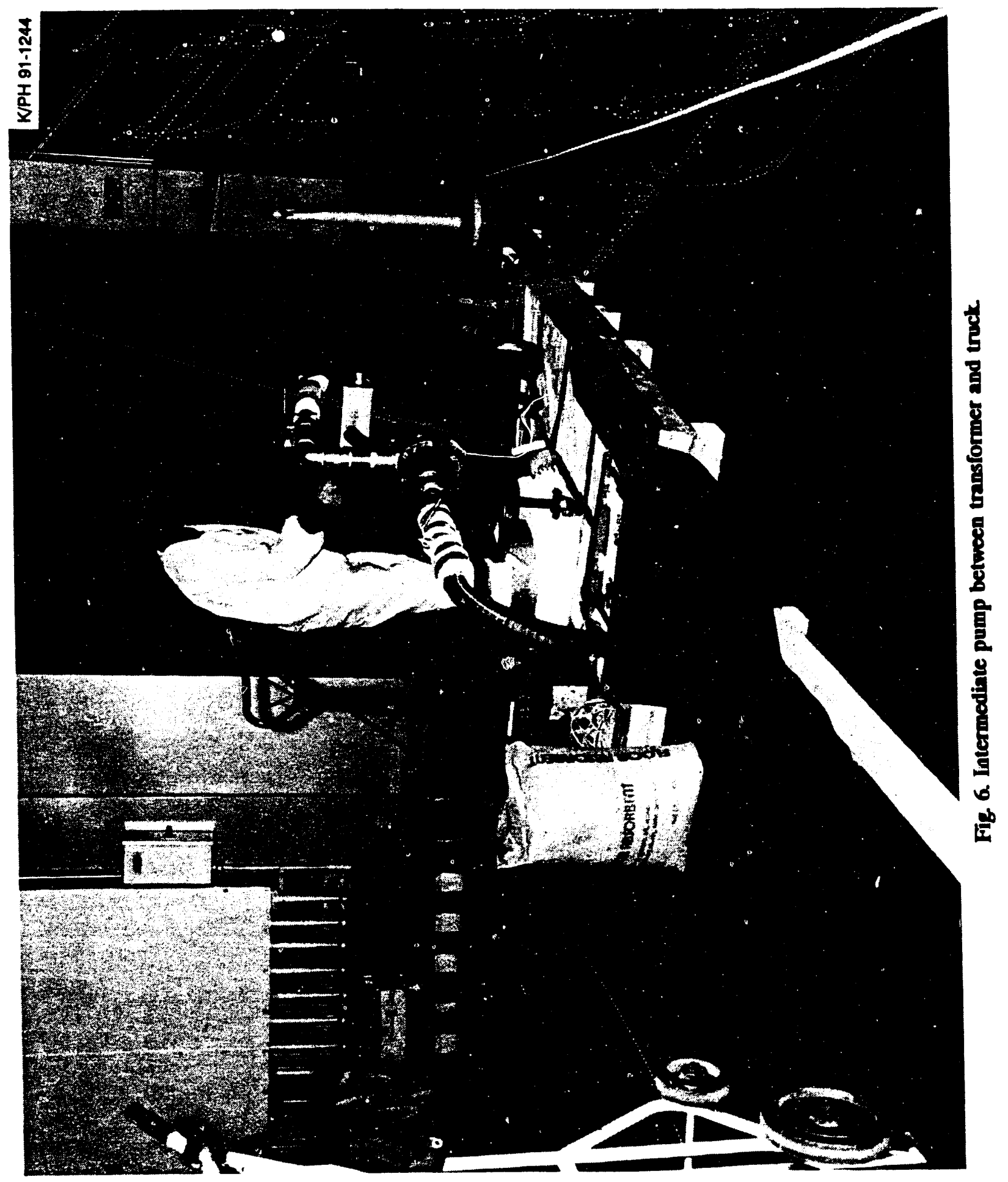




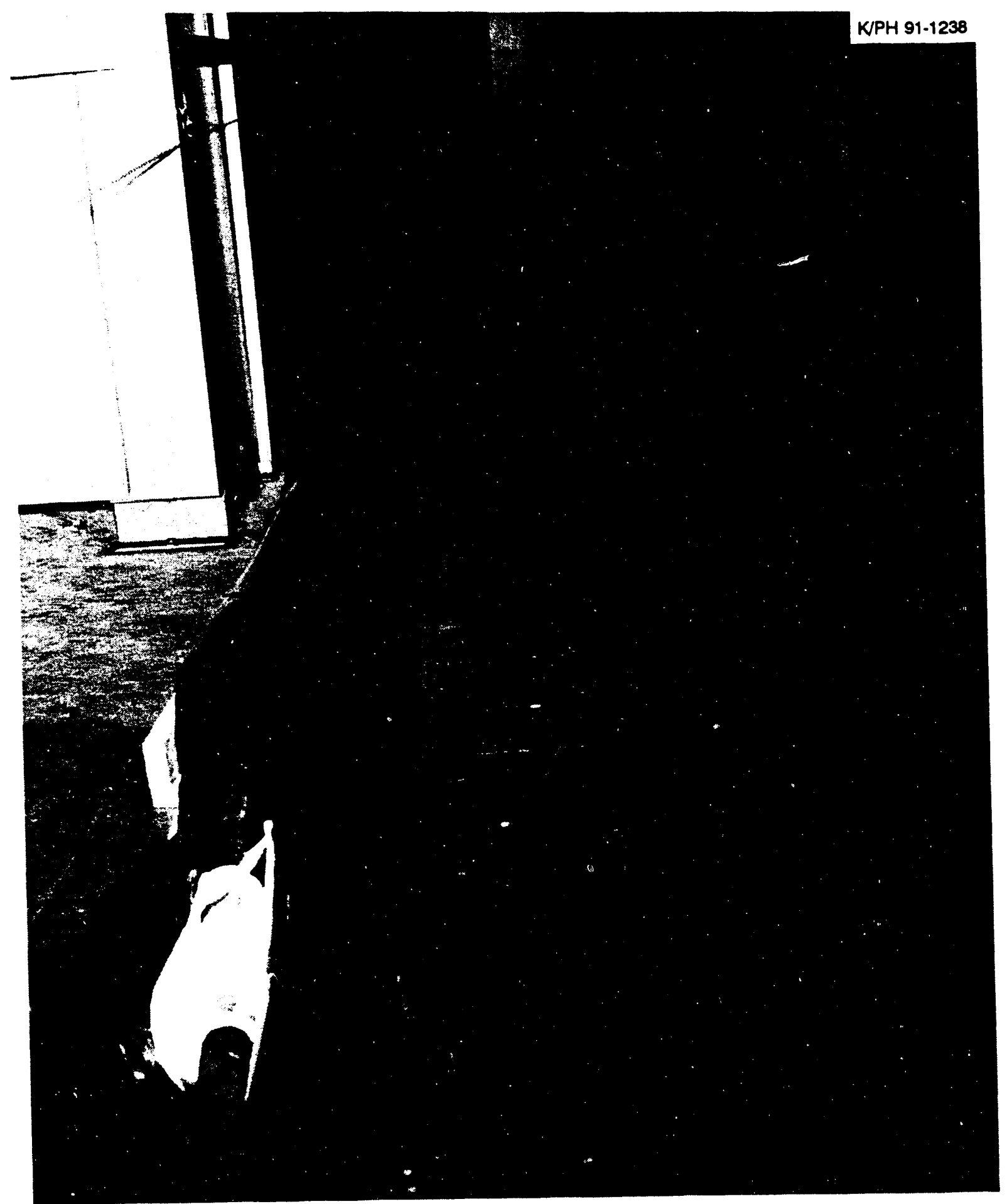

Fig. 7. Containment for protected line to conduct fluid to truck. 


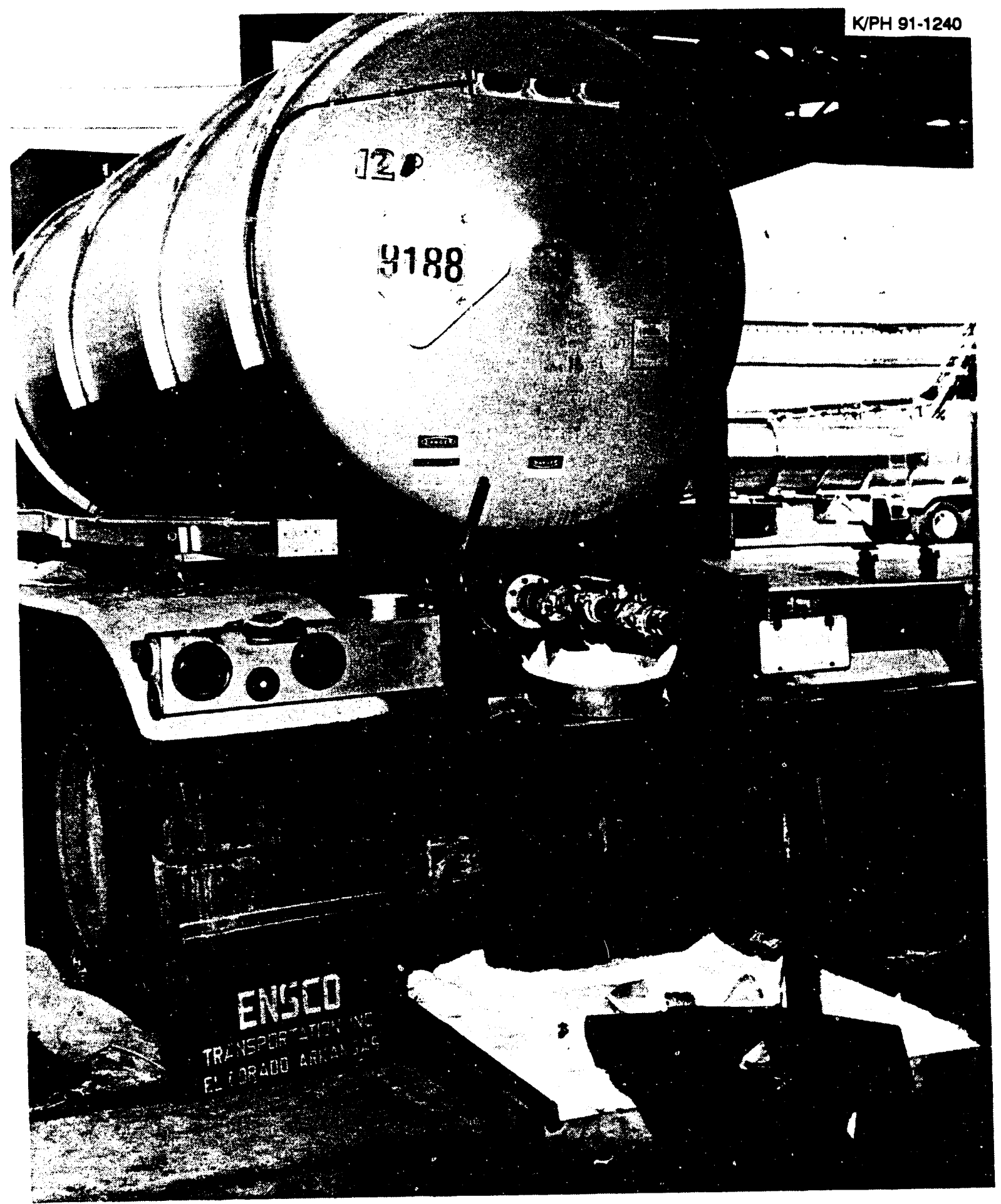

Fig. 8. Arrangement for transferring fluid into a vacuum truck 
We had planned to dispose of an additional 40,000 gal of mineral oil at an off-site facility in FY 1991. We had prepared a bid specification and received several bids but were forced to stop off-site removal because of DOE's moratorium on off-site disposal of waste starting in May. We are now planning to dispose of this material in the TSCA incinerator in FY 1992.

We have continued our preparations to plan the removal of the transformer carcasses in K-33. Maintenance finished disconnecting 77 process transformers in FY 1991.

\subsection{POLYCHLORINATED BIPHENYL VENTILATION GASKET SPILI. CONTROL/REMOVAL}

We started the PCB gasket removal project to address the draft FFCA Attachment II item (E), "Gasket Removal Program and Ventilation Duct Management." Figure 9 indicates the scope of the project relative to the typical process unit arrangement in K-33, K-31 and K-29. We notified EPA before August 1, 1991, that we had started the project work associated with removing gasket material and with decontaminating ventilation ducts as required by the draft FFCA.

During FY 1991 we issued a feasibility study covering the removal of PCB gaskets from the K-25 process buildings motor ventilation ducts. As part of this feasibility study, we determined that the motor ventilation systems in the K-33, K-31 and K-29 process buildings consist of $\sim 8500$ gaskets and $1,000,000 \mathrm{ft}^{2}$ of sheet metal. Table 1 summarizes in detail the motor ventilation materials.

As a part of the feasibility study, we estimated the cost of two alternatives for resolving compliance issues associated with the PCB gaskets. Alternative A was for removing the gaskets and duct, and Alternative B was for removing only the gaskets and leaving the ventilation duct in place. Table 2 summarizes the cost estimates. DOE has directed us to use Alternative A, so we are pursuing the gasket removal project accordingly.

Also, during FY 1991 we planned to demonstrate the removal and cleaning of $50 \mathrm{ft}$ of ventilation ductwork. We did the initial field work in preparation for this activity, including the removal of a ventilation duct end plate and associated gasket (Fig. 10 shows removal process; Fig. 11 shows the end plate and gasket removed). However, due to changes in the FFCA, it was decided that a demonstration was no longer required. We then stopped all demonstration activities.

We began to prepare a technical proposal package for removal of motor ventilation gaskets and ductwork in K-33 and issued a Commerce Business Daily notice for the pending K-33 duct removal contract. We expect to finish the technical proposal paclage in third quarter FY 1992 and believe the proposal will win a contract for removal of gaskets in the $\mathrm{K}-33$ building in second quarter FY 1993 . The contract value is estimated to be about $\$ 50$ million. 


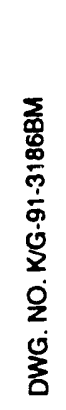

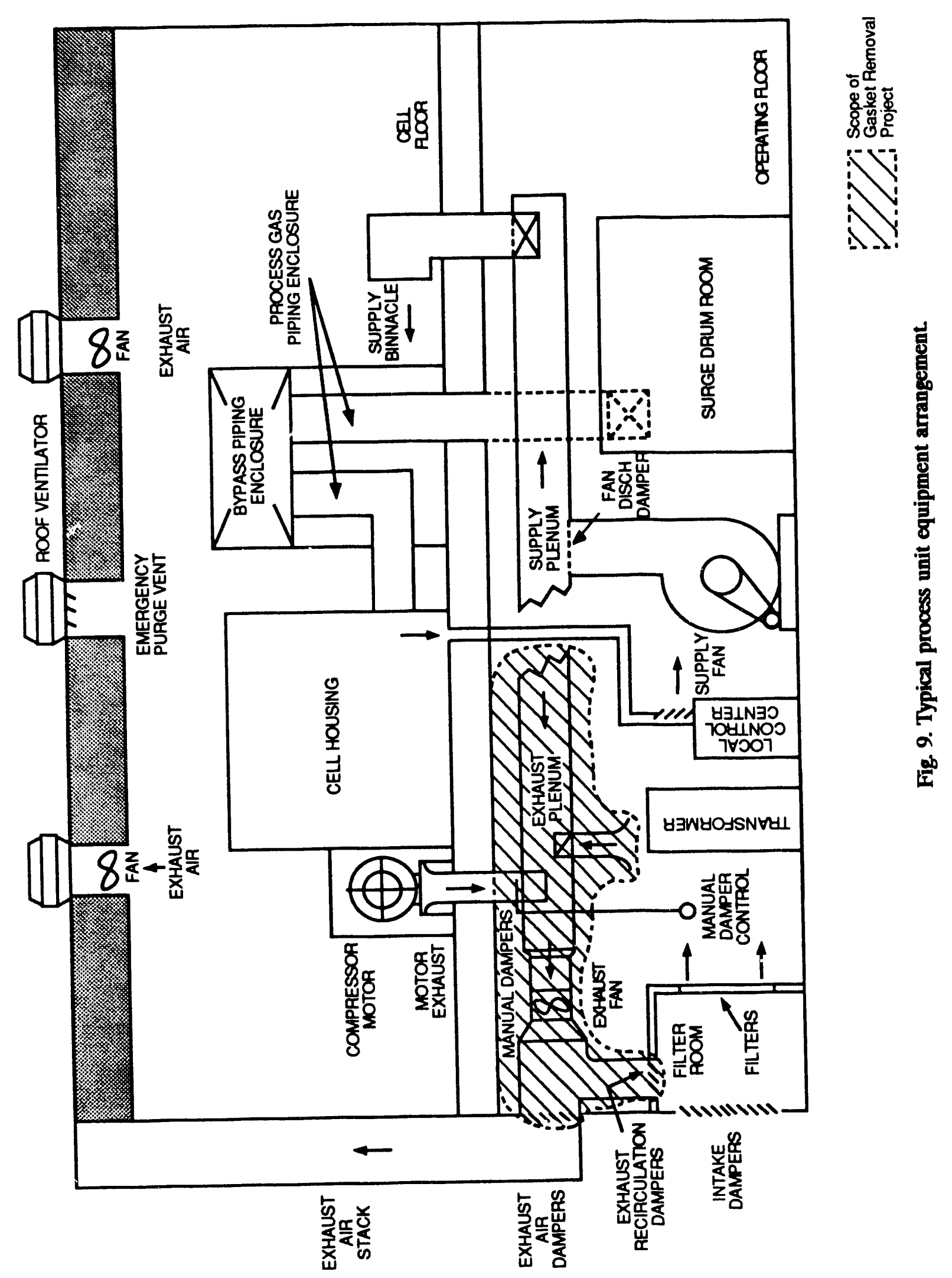




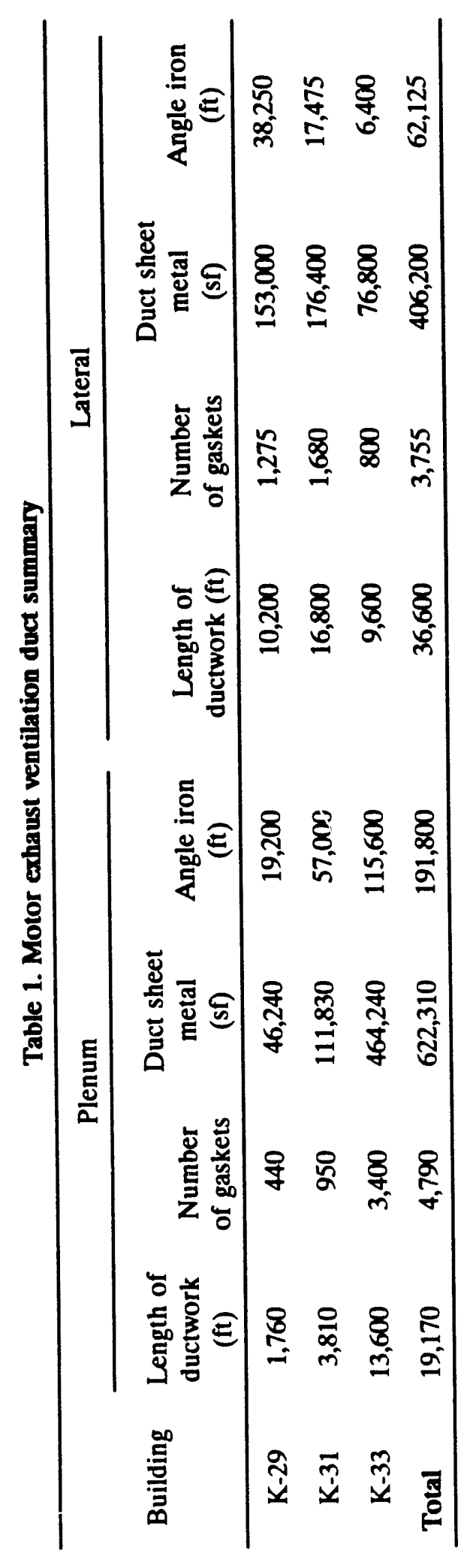


Table 2 Summary of cost estimate

\begin{tabular}{lcc}
\hline & \multicolumn{2}{c}{ Cost $\left(\$ \times 10^{6}\right)$} \\
\cline { 2 - 3 } & Alternative A & Alternative B \\
\hline Engineering & 20 & 19 \\
Spill control & 1 & 1 \\
Development & 7 & 7 \\
Removal & 75 & 89 \\
Cleaning & 66 & 0 \\
Storage/disposal & 31 & 7 \\
Subtotal & 200 & 123 \\
Contingency & 60 & 37 \\
Total & 260 & 160 \\
\hline
\end{tabular}


28

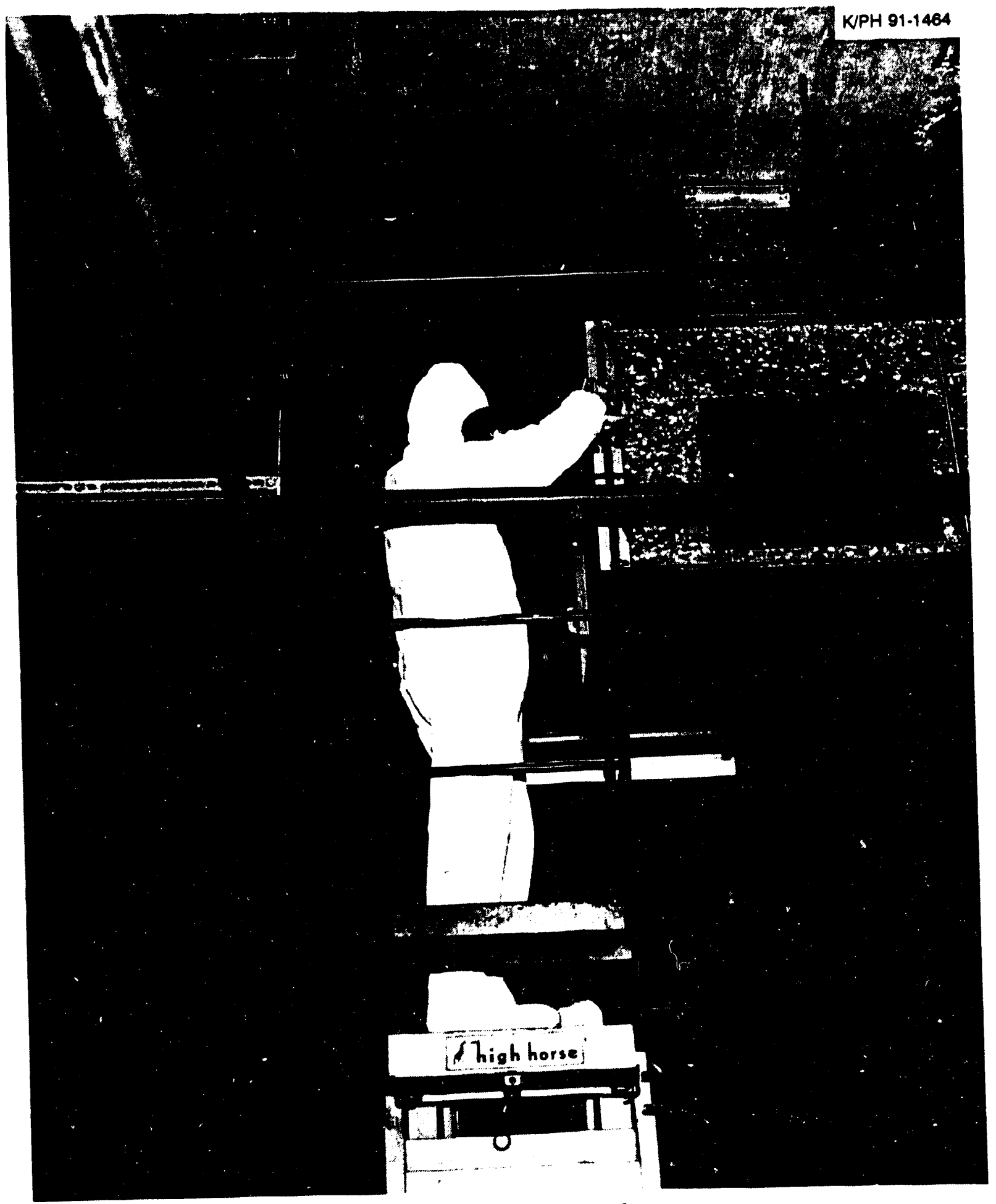

Fig. 10. Ventilation duct removal process. 


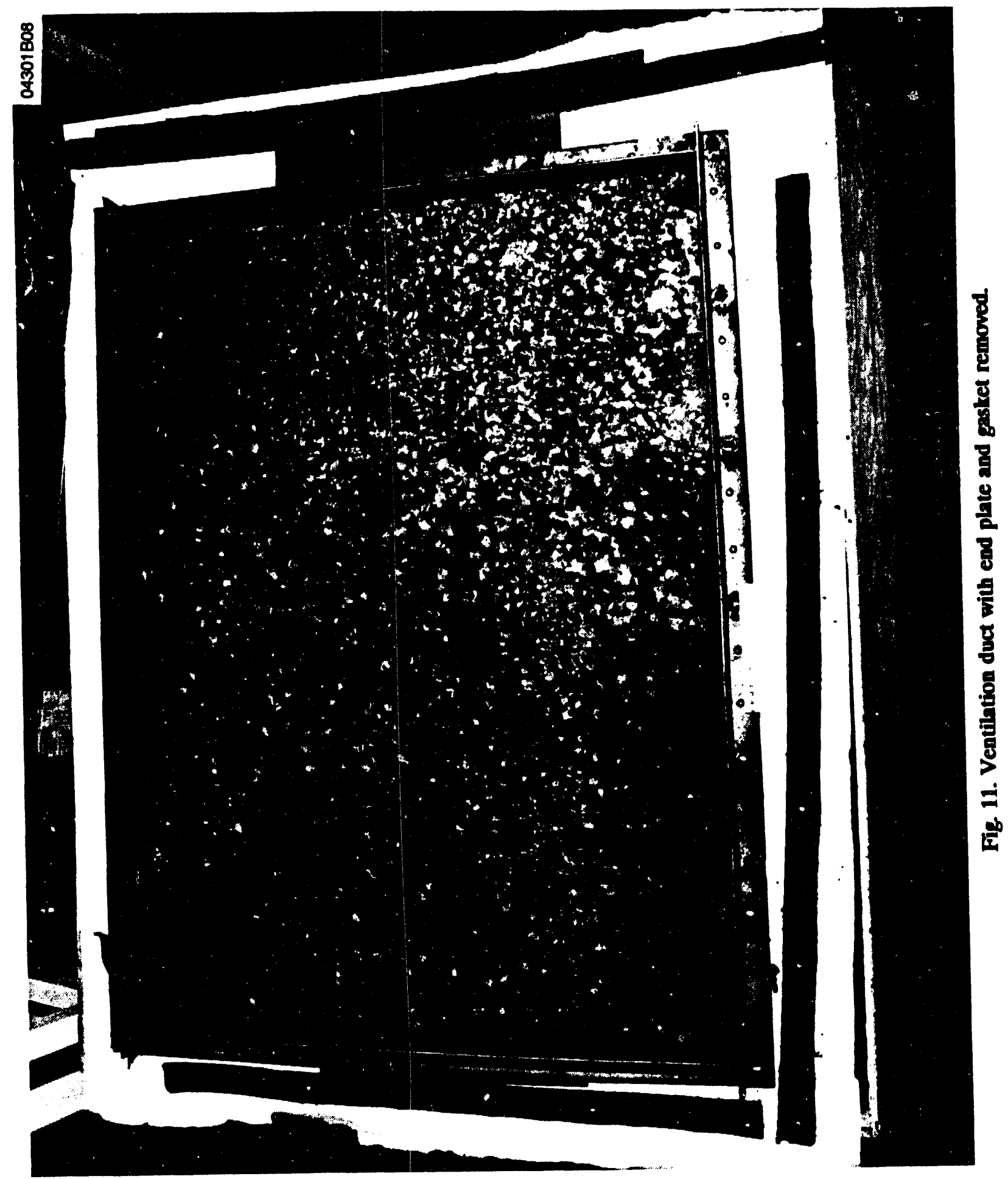




\subsection{RADIOLOGICAL CONTAMINATION CONTROL}

Radioactive hazards at the K-25 Site, principally uranium and technetium, fall into two categories: internal contamination (confined within the process systems) and residual external contamination. Uranium contamination inside the process equipment is enclosed primarily within welded systems and can be safely left in place until Phase II of D\&D. Exposed building surfaces will be controlled commensurate with the anticipated use of the facility.

Our primary efforts to control radiological contamination in FY 1991 were to upgracie the boundary control stations (also known as radiation monitoring stations, or frisker stations) in the K-25 Building ( 2 locations), and in K-27, K-29, K-31, and K-33. These upgrades are part of our effort to control exposure of personnel to levels of contamination that are as low as reasonably achievable (ALARA), as required under DOE Order 5480.11. These upgrades included improving and enlarging the areas to include proper clothing requirements under the new anti-contamination (anti-c) clothing policy. This included keeping the ingress and egress areas physically separated from each other. The improved boundary control stations also included new hand and foot monitors that allowed personnel to monitor both their feet and hands at the same time. The boundary control stations include alpha and beta/gamma radiation detection instruments to monitor the entire body for contamination, step-off pads and corresponding markings to designate the start of the clean area, clean and dirty clothing containers, and tables, cabinets, etc. for respirators and clothing. We finished the facilities at K-25 and made significant progress on the other areas, and we expect these areas to be completed in FY 1992.

In order to complete these boundary control stations, we used decontamination techniques that included a concrete scabbler, a "corner cutter" (a scabbling device that decontaminates and removes surface materials in tight corners), washing with detergent and water, wiping with cloths, or vacuuming with HEPA filtering systems to decontaminate the clean areas at the boundary control stations. Waste material generated from these decontamination activities were contained and stored as radioactive waste.

We also decontaminated and reopened selected change houses and break areas. A change house and break area in the K-33 building was reopened in order to allow maintenance to staff a crew in this building. A change house was also reopened in $\mathrm{K}-27$ for subcontractor personnel who are removing asbestos in D\&D facilities.

\subsection{SPECIAL PROJECTS}

\subsubsection{Cooling Towers}

We plan to demolish shutdown cooling towers at the K-25 Site in order to remove the wooden structures as they deteriorate and become fire hazards. The structures contain primarily treated wood, with varying amounts of asbestos, metal, and polyvinyl chloride/ fiberglass. A subcontractor prepared an Alternatives Assessment to evaluate options for demolition and waste management. The subcontractor preferred clamshelling for demolition of the cooling towers but noted that disposal requirements for the demolition wastes will vary depending on the contaminant levels in the wood and other materials. The wood contains contaminants such as chromium, arsenic, organic fungicides, and trace levels of dioxins and uranium from previous operation and treatment of the cooling towers to support the K-25 
Site. We are planning to characterize the cooling towers for 1992 as input for waste management plans. Burial at the replacement to the Y-12 Sanitary Landfill II may be feasible if contaminant concentrations are low and nonleachable. Removal of the cooling towers is receiving increased priority as the towers continue to deteriorate, increasing the risk of fire. We have evaluated the risk and impact of a fire and concluded that the fire risk increases with time and that a fire could spread contaminants for some distance around the towers.

\subsection{Electrical Compliance}

The permanent shutdown of nonessential electrical systems in the process and support facilities was evaluated in FY 1991, and limited compliance activities were initiated to eliminate porential safety hazards. Some major electrical systems were permanently disconnected when the plant shut down; the remaining systems must be evaluated and deenergized so as to leave only those electrical sources required for future surveillance or D\&D activities. This year we inspected the shutdown facilities to identify electrical deficiencies and took corrective actions. A significant effort was begun to permanently de-energize the electrical systems in the K-27 process building; next year we will finish this work in K-27 and extend it to the $\mathrm{K}-25$ and $\mathrm{K}-29$ process buildings.

\subsubsection{Uranium Deposit Removal}

Activities associated with the Deposit Removal Project for FY 1991 focused on health, safety, environmental, and security documentation. We finished several documents in preparation for a readiness review that vrill take place before the project starts. DOE has approved these documents.

We wrote and submitted to DOE-OR for approval the Material Balance Area Security Plar1, which they approved on July 30,1991. The plan addresses the security requirement for the Deposit Removal Project as well as security upgrades for the building. Once the approved security changes are made, we will save about $\$ 500,000$ a year. These changes have been started and will be finished before the Deposit Removal Project starts.

In preparation for uranium samples at $>5 \%$ assay to be analyzed, a summary security plan for the K-1004 laboratory, completed in Dicember 1990, is pending revision and completion after finalization of the Deposit Removal Project plans. We have eliminated security concerns at the K-1004 laboratory by agreeing with the Y-12 Recovery Management, Nuclear Materials Control and Accountability, and Security organizations that all analysis will be conducted at the Y-12 Plant.

We finished a Fire Suppression/Training Plan, and the Fire Protection Department approved it on July 24, 1991. The plan, entitled Management and Operation of Automatic Sprinkler Systems Associated with the Deposit Removal and Equipment Decontamination Project, K-FPP-3.3.12, describes responses to fire scenarios for the process building; it also addresses concerns about Deposit Removal Project activities.

Y-12 and K-25 nuclear materials control and accountability (NMC\&A) managers wrote and approved a shipper/receiver agreement for the Deposit Removal Project. The agreement allows the nuclear materials collected during the Deposit Removal Project to be shipped at nondestrive assay values pending destructive analysis by the Y-12 Laboratory. 
We completed several safety assessments in preparation for the Deposit Removal Project: for equipment removal and cleaning (K/D-SA-2130, Rev. 1), completed, approved, and issued on August 5, 1991; for on-site transportation and packaging of uranium deposit removal material and equipment (K/D-SA-2166, K/D-SA-2168), completed and issued for approval on August 29, 1991.

On December 10,1990, we finished a criticality safety analysis for the Deposit Removal Project, Phase I activities. We began and finished appropriate criticality safety assessments. Now that we have sealed and isolated the process openings, we have started a criticality safety analysis to evaluate the issues associated with the uranium deposits pending removal.

We finished a quality assurance plan for the Deposit Removal and Equipment Decontamination Project in August 1991 and completed the third revision of an operations flow plan on August 29, 1991. These plans address the roles and responsibilities associated with the uranium deposit removal flow and interfaces required during the project.

On April 10, 1991, we completed a special test to disassemble a compressor (Figs. 12 through 14) in the K-27 Building. Our purpose was to demonstrate our capability to dismantle the equipment and to verify the disassembly procedures. The test was successful, and we identified no major issues.

The Technical Division has begun a laboratory experiment in $\mathrm{K}-1004 \mathrm{~L}$ in support of the Deposit Removal Project. The experiment is designed to test the gas phase removal process using fluorides and other plausible chemicals.

\subsection{FACILITY SURVEILLANCE AND MAINTENANCE}

S\&M ensures that the process facilities remain in a safe, environmentally sound condition. Surveillance ensures that we (1) find fallen or exposed friable asbestos; (2) identify PCB leaks and take appropriate corrective action; (3) detect wasteful utility leaks; (4) find and correct hazardous material leaks that might result in environmental insult; (5) keep in working condition all criticality alarm systems, fire protection systems, and security systems; (6) maintain electrical lighting and other essential electrical equipment in accordance with OSHA regulations; (7) provide janitorial and custodial care to ensure that acceptable health and safety standards are met; and (8) inspect and inventory $\mathrm{UF}_{6}$ cylinders. Maintenance is needed to correct environmental health and safety deficiencies. 


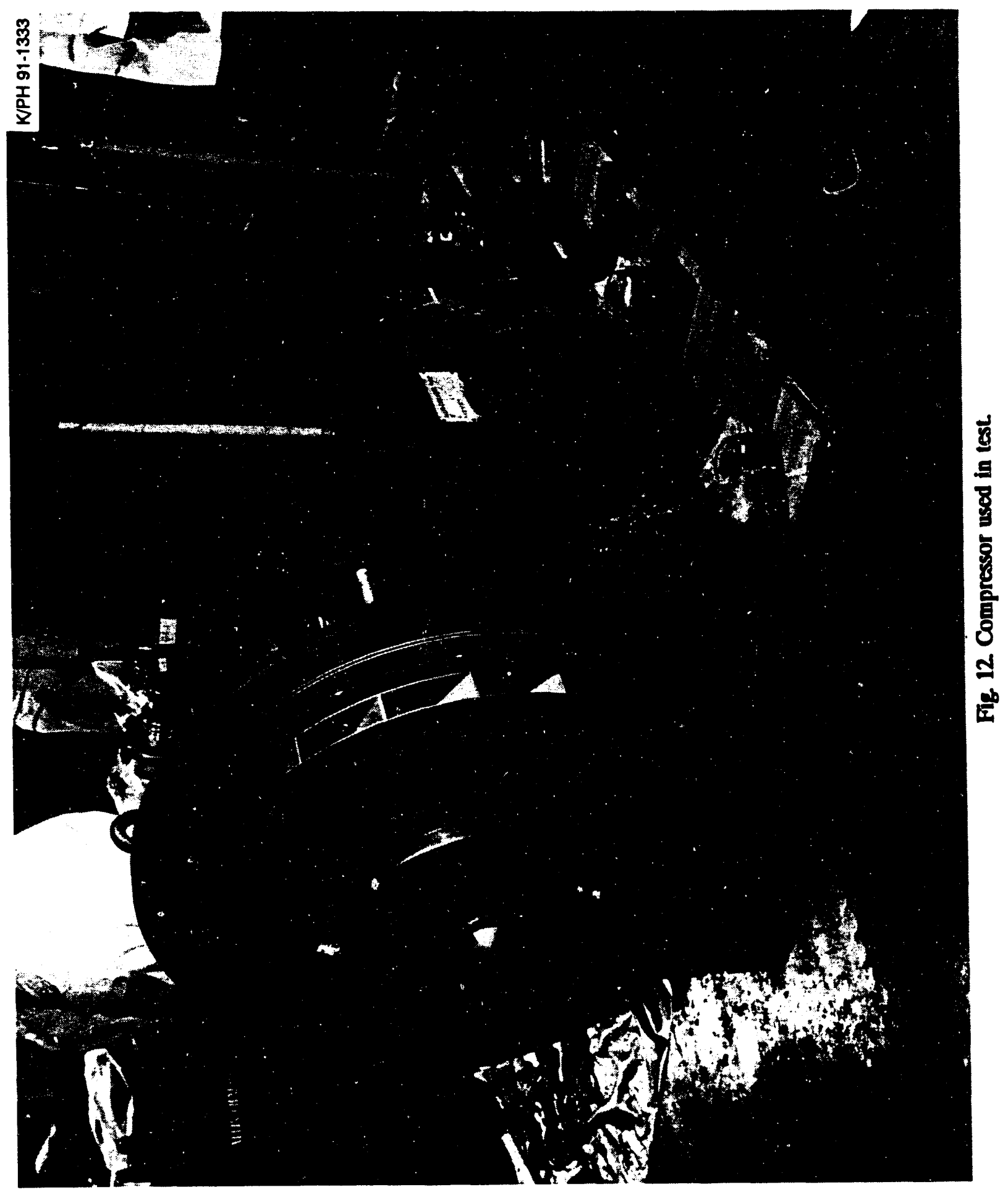




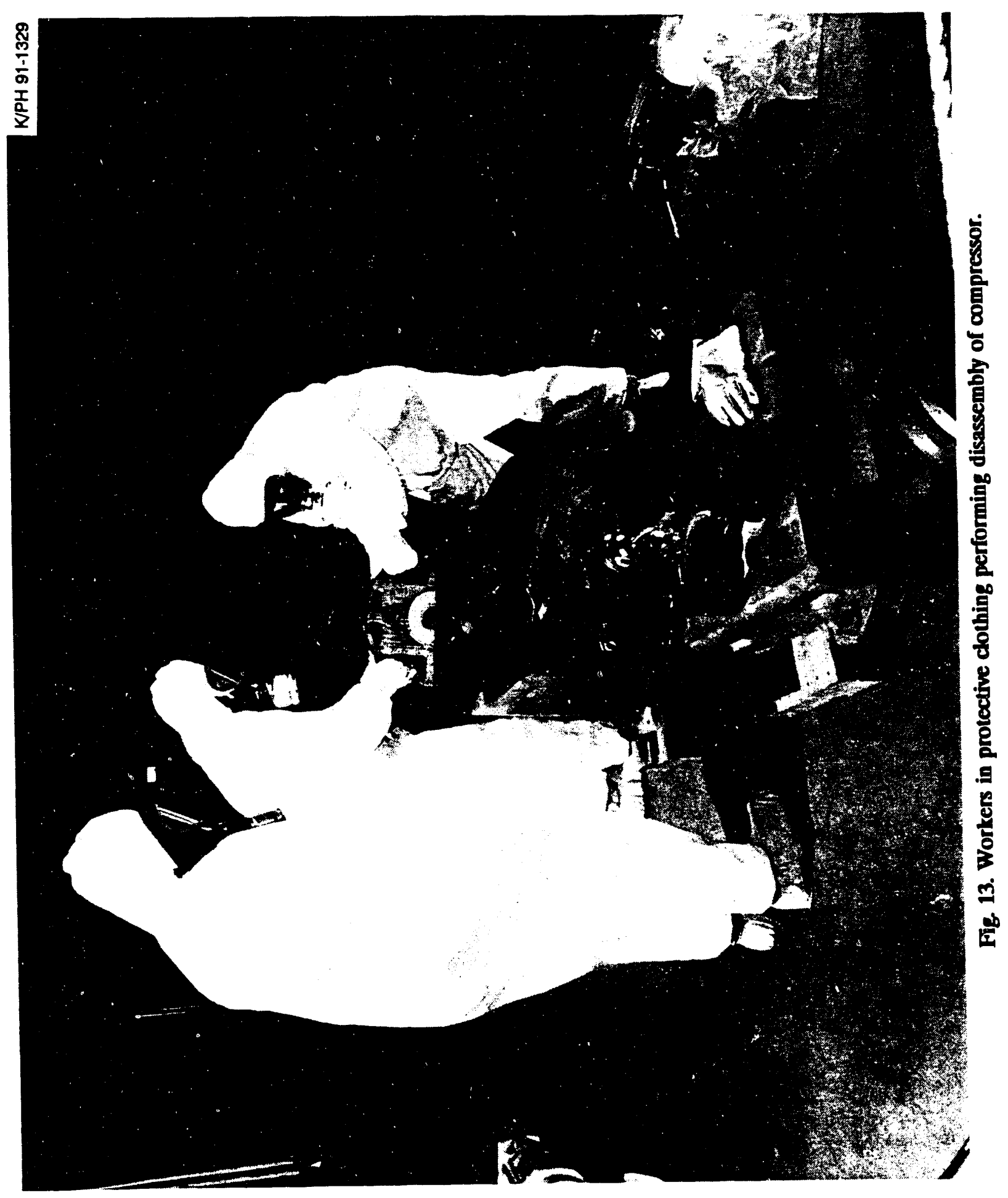




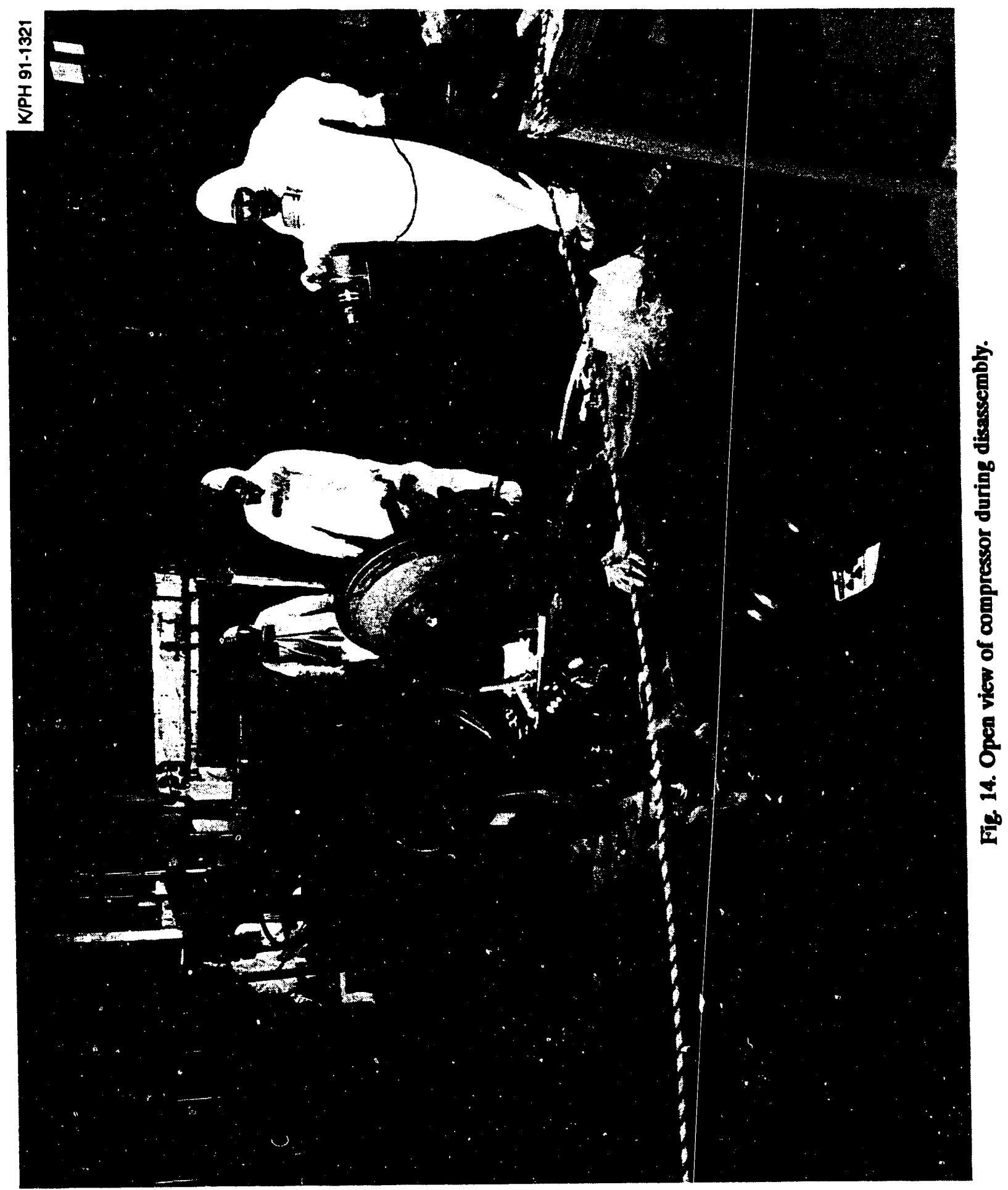


Our surveillance activities include

- Cleanup and sampling of 68 PCB leaks from ventilation duct gaskets

- Monthly inventory and inspection of lube oil and coolant storage tanks

- Periodic facility walk down inspections

- Semiannual $\mathrm{UF}_{6}$ cylinder inspection

- Annual $\mathrm{UF}_{6}$ cylinder inventory

- Semiannual asbestos survey

- Thirty-day inspection of $\sim 3500$ PCB waste drums

- Facility cleanup and management of low-level radioactive material

In the appendix you will find descriptions of surveillance frequencies and various forms used for documentation of surveillance activities, including checklists that provide documentation of activity completion, corrective actions required for noted deficiencies, and maintenance job requests for correction of deficiencies. Form titles are

- Site Facility Operations Documentation of PCB Gasket Trough Installation (UCN17597)

- Site Facility Operations PCB Spill or Drip Documentation (UCN-17595)

- Site Facility Operations PCB Spill Cleanup Results (UCN-17598)

- Site Facility Operations Operator Check of Facility for PCB Leaks (UCN-pending)

- Site Facility Operations Weekly Review to Check for PCB Leaks (UCN-pending)

- Lube Oil, Coolant Station Inspection Sheet (UCN-pending)

- Site Facility Operations Freon Inventory-Building K-31 (UCN-pending)

- Site Facility Operations Freon Inventory-Building K-33 (UCN-pending)

- General Building Inspections (UCN-pending)

- K-25 Site UF 6 Cylinder Inspection Log Sheet

- K-25 Site Asbestos Walk-Through Inspection and Assessment Form (UCN-pending)

- B-25 Box Inventory for Building/Storage Area (UCN-pending)

\subsubsection{Roof Repairs}

The program to repair and maintain roofs of the shutdown gaseous diffusion facilities has continued with over 90 areas identified and repaired in FY 1991. Surveys continue to locate possible water inflow points in the process buildings.

\subsubsection{Criticality Safety}

Activities associated with criticality safety included closure of process openings and radiation fencing. Specifically, 1716 openings in the K-27 and K-29 buildings were identified and closed.

\subsubsection{UF 6 Cylinder Program}

We finished the annual inventory of the $\mathrm{UF}_{6}$ cylinders at the $\mathrm{K}-25$ site in November 1990. The semiannual inspection of the storage yards, completed in July 1991, revealed no new indications valve leakage or other problems.

Ongoing programs that improve the safety and reliability of the long-term $\mathrm{UF}_{6}$ storage include the following. 
- Cylinder Corrosion Monitoring Program

- Cylinder Life-Cycle Study

- Safety analysis reviews of field maintenance of cylinders

- Sampling of the environment around the cylinders (e.g., soil, concrete).

In September 1991, a technical program manager took charge of the $\mathrm{UF}_{6}$ Cylinder Program at the K-25 Site. This program manager, dedicated full-time to the Cylinder Program, will evaluate the current activities, define near-term corrective actions, and design an improved program. The improved program will develop formal procedures and guidelines, incorporating Conduct of Operations standards and Best Management Practices. It will also project long-term actions for the safe storage of the cylinders, pending decisions on the ultimate disposition of the $\mathrm{UF}_{6}$ material. The final goal of the evaluations is to issue a longterm Surveillance and Maintenance Program Plan with estimated budget requirements. 


\section{K-25 CENTRIFUGE}

DOE has made Energy Systems responsible for maintaining the unused, contaminated centrifuge facilities at the K-25 Site. S\&M of these facilities will continue until they can be cleaned up and used in some way.

The K-25 Centrifuge D\&D program consists of the following facilities: K-101, K-797, K-798, K-1004-J, K-1004-Q, K-1023 (including K-1009-A), K-1045, K-1052, K-1200 south bay, K-1210, K-1210-A, K-1220, and K-1600. Requested funding covers the following activities: (1) routine maintenance, (2) emergency repairs, (3) power and utilities, (4) environmental protection, (5) security, (6) fire protection, (7) janitorial services as required, and (8) management oversight.

The two major tasks for our K-25 Centrifuge program are to survey and maintain facilities and to store or dispose of the hazardous centrifuge equipment and materials.

The primary objectives of the S\&M task are to prevent the centrifuge facilities from deteriorating and to fund plant services, inspection, and maintenance repairs associated with these facilities. We periodically inspect the facility and make repairs (as necessary) to prevent deterioration and to comply with standards for fire protection, safety, security, and environmental protection. Minimum levels of heating and ventilation are necessary for facilities with wet sprinkler systems.

The task of storing/disposing of hazardous centrifuge equipment and materials requires us to manage, make plans for, and report on any interim and/or long-term storage and disposal of hazardous centrifuge equipment and waste materials. The principal activities funded in this task are (1) surveillance and monitoring of stored equipment and materials, and (2) disposal and/or long-term storage of process materials, both from the K-25 Site and from other locations (materials shipped in to expedite closure of centrifuge manufacturer facilities).

Approximately 50 trailer loads of contaminated and/or hazardous equipment and materials brought in from the former centrifuge manufacturers remain for disposal or storage. Also, we are keeping in temporary storage an additional 25 trailer loads of equipment left over from the former centrifuge development program until we can pack it appropriately for long-term storage and/or disposal. Though it results in long-term storage and surveillance needs for many items, we must store classified and contaminated materials and equipment until they can be declassified.

\subsection{SURVEILLANCE AND MAINTENANCE}

S\&M activities during FY 1991 included daily, weekly, and monthly observations and inspections:

- Daily observations for abnormal system operation and leaks in auxiliary supply lines such as water, steam, and air

- Weekly inspections of eye baths (including operating them for $1 \mathrm{~min}$.) 
- Monthly checks of fire extinguishers

Other S\&M activities were as follows:

- Walk-through inspections of the K-25 Site former centrifuge buildings by ES\&H to identify any anomalies in the buildings, systems, and hardware.

- Routine maintenance of buildings and systems, as necessary, to keep them from deteriorating and to comply with standards for fire protection, health, safety, security, and environmental protection. These routine repairs included leak repairs on roofs; heating, ventilating, and air conditioning equipment coils; pipes; heat exchanges; steam condensate lines; and valves. We also repaired and maintained as necessary the electrical system battery chargers.

- Relamping, repair, or replacement of emergency lighting fixtures to provide adequate emergency lighting as determin zd by OSHA inspections. We made emergency repairs on roofs and repaired firewater piping and sprinkler heads as required.

- Routine preparation for operating the appropriate building air-handling units before winter (heating) and summer (cooling) seasons. This required us to inspect drive belts and, where necessary, replace filters and lubricate equipment.

- Removal of the underground storage tanks for diesel fuel at the shutdown Centrifuge Plant Demonstration Facility (Building K-1220).

- Provision of building power and utilities, as necessary, to maintain minimum safe lighting and minimum heating (to prevent freezing of firewater and other water piping).

- Periodic checking of fire extinguishers, provision of building janitorial services, extensive radiological surveying to establish "clean areas," maintenance of uranium accountability, and submission of a quarterly uranium inventory.

Other activities included implementation of a new Conduct of Operations lockout/tagout procedure to further enhance worker safety during maintenance on equipment. In addition, OSHA conducted several inspections of the Centrifuge D\&D facilities, and the findings are being closed out.

\subsection{HAZARDOUS CENTRIFUGE EQUIPMENT AND MATERIALS STORAGE AND DISPOSAL}

We removed from storage and transported to K-25 Site Property Sales $\sim 11$ truckloads of surplus equipment and $2000 \mathrm{lb}$ of lead bricks. We also removed from storage more than seven truckloads of scrap metal, taking it to the K-25 Site Scrap Metal Yard, and five truckloads of scrap wood, moving it to the Y-12 Salvage Yard. This effort, combined with consolidation of equipment and materials, resulted in an $-10,000-\mathrm{ft}^{2}$ reduction in requirements for the hazardous material storage area. 
We surveyed and monitored the stored materials weekly and monthly, overpacking leaking drums as required, while maintaining uranium accountability and submitting a quarterly uranium inventory. 


\section{Appendix}

\section{SURVEILLANCE ACTIVITY SUPPORTING INFORMATION FOR THE K-25 SITE D\&D PRGGRAM}


SURVEILLANCE INSPECTION FREOUENCIES

\section{SURVEIILANCE INSPECTION}

1. Complete building inspection for new PCB spills from PCB gaskets, existing troughs, and electrical cable trays in the vicinity of gasikets. Areas which have been flagged as a PCB spill site should be checked and llagging maintained until lab samples confirm cleanup to acceptable levels.

2 Inspection of all locations with known, active PCB leaks. An active leak means a location leaving evidence of one or more drips per week Locations subject to have active leaks are PCB gaskets, troughs, electrical cable trays, and transformers. If the absorbant pads are stained, the pads must be changed. A list should be maintained for active leakers and updated weekly by the building supervisor.

3. NMC\&A Perpetual Inventory of Sensitive Locations

4. The tamper indicating devices (TIDs) used by D\&D personnel to secure designated areas do not need to be checked daily. TIDs must be checked during inventory activities such as each time a physical inventory inspection is performed in one of the secured areas. When the TID number is removed, it should be checked, documented. and recorded to match the number of the last TID placed at that location. Also, if entry is required for maintenance repairs or other activities the TIDs should be cross-checked.

5. Physical inspection of large deposits.

6. Support of Security Personnel Alarm System Checks.

7. Barrier Protection Cell Pressure Check (2 psig or above.)
FREOUENCY

Weekly

Daily

Monday- Friday, except on holidays.

During a Schedule physical inventory and each entry into these special areas.

None required

Weekly

Weekly

UCN-10325 (1 12-50) 
8. K-25 Building Non-SNM Door Openings.

9. General Building Inspections for HS\&E (document roof leaks, lube oil spill cleanup, document fallen asbestos and unsafe conditions, operator cleanup and housekeeping deficiencies, areas needing maintenance attention, etc.).

10. Frisker Station Checks (K-25, K-27, K-29, K-31, K-33).

11. Frisker Station Checks (K-1131, K-413, K-631, K-633 K-131).

12. Freon Inventory

13. Fissile Storage Areas

14. PCB inventory

15. Sprinkler Inspections

16. Surplus Materials Check at Storage Locations.

17. Vehicle Inspections. Send to Safety, Fleet Manager before the fifth day of the month.

18. Safety Equipment Inspection.

19. Low-Level Waste Storage Inventory.
Monday thru Friday at 0900 hours, except holidays.

Weekly

Daily

Weekly

Second Week in Each Month.

Third Week in Each Month.

First Week in each Month.

Third Week in each Month.

Second Week in each Month.

Fourth Week in each Month.

Fourth Week in each Month.

TBD

\section{INTERDM ADMINISTRATIVE PROCEDURE FOR CHECKSHEEIS:}

Any deficiency should be indicated by the operator on the chechsheet, and if corrected, noted as such. All checksheets should be signed and dated by the operator and the supervisor. Any items requiring further attention should be specifically denoted on the checlesheet along with a statement of the corrective action planned. If maintenance is required, a work order should be prepared and given to the maintenance coordinator. The checlesheet with the maintenance deficiency denoted should also be given to the maintenance coordinator for followup. When repaired, the checlsheet should be marked by the maintenance coordinator and returned to the supervisor. The supervisor should confirm that the maintenance repairs were adequate, sign to document final acceptance, and file the checksheet. If repairs are not adequate, the checkstheet should be returned to the maintenance coordinator. vent 10025C
$(6 \quad 7.90)$ 


\section{SITE FACIIITY OPERATIONS \\ DOCUMENTATION OF PCB GASKET TROUGH INSTALLATION}

This portion is to be filled out by Decontamination and Decommiscion Project

Description and location of PCB ventilation gasket needing the installation of a trough:

Building Number

Spill Number

Column Number

Sketch of spill location

Supervisor Signature

Date

This portion is to be filled out by Maintenance

Date trough installed

This signature documents that the trough needed in the location described above has been installed.

Maintenance Signature

Date

THIS FORM SHOULD BE RETURNED TO THE BUIIDING SUPERVISOR

UCN.17597

(1 7.91) 


\section{SITE FACIUITY OPERATIONS \\ PCB SPILL OR DRIP DOCUMENTATION}

Building No.

\begin{tabular}{|l|l|l|l|l|l|}
\hline Spill No & Date Spill & Time Spill & Size of & Date & Time \\
\hline & & & & & \\
\hline
\end{tabular}

Spill Source:

Column Location:

Materials Contaminated:

Sample Numbers

Precleaning:

Postcleaning:

Cleaning material used (penetone, hexane, etc.)

Mark the spill location: (Use columns, equipment, or other identification to clearly identify location of the spill.

Additional Requirements:

The time between the spill discovery and cleanup should not exceed 24 hours.

The visible spill area plus 3 feet must be cordoned off.

The cir uning must be done with a double wash/rinse method.

Cleaning materials must be stored in proper PCB containers and put in PCB storage areas.

Operator Signature:

Date:

Supervisor Signature:

Date:

UCN-17595

(1 7.91) 
SITE FACIIITY OPERATIONS

PCB SPIIL CLEANUP RESULTS

Building Number

Spill Number

Precleanup (If Applicable)

Sample Number Date Sample Taken

SampleDescription

Sampie Results $\left(\mu \mathrm{g} / 100 \mathrm{~cm}^{2}\right)$

Postcleaning

Sample Number Date Sample Taken

SampieDescription

Sample Results $\left(\mu \mathrm{g} / 100 \mathrm{~cm}^{2}\right)$

If multiple attempts have been made to clean (and sample) the same spill, which attempt is this sampling result (2nd. 3rd. etc.)?

If a different cleaning material has been used than the initial attempt, specify the cleaning method used

If the spill has been cleaned to $10 \mu g / 10 \mathrm{~cm}^{2}$ or less. the spill cleanup is complete.

Signature Date

UCN-17598

$\left(\begin{array}{ll}1 & 7.91\end{array}\right)$ 


\section{SIIE FACIIITY OPERATIONS}

Operator Check of Facility for PCB Leaks

This form is to document that a weekly check of the facilities containing PCB gaskets was performed. If leaks are found, they should be documented on form "PCB Spill or Drip Documentation" (UCN.?595).

Building:

Date:

Operator Signature:

The completed form should be turned in to the enpervisor. As an alternative. the operator may fill out and comple:e the "Weekly Review to Check for PCB Leaks."

UNC. (Poming 
SIIE FACIIITY OPERATIONS

Weetly Review to Chect For PCB Leabs

Building:

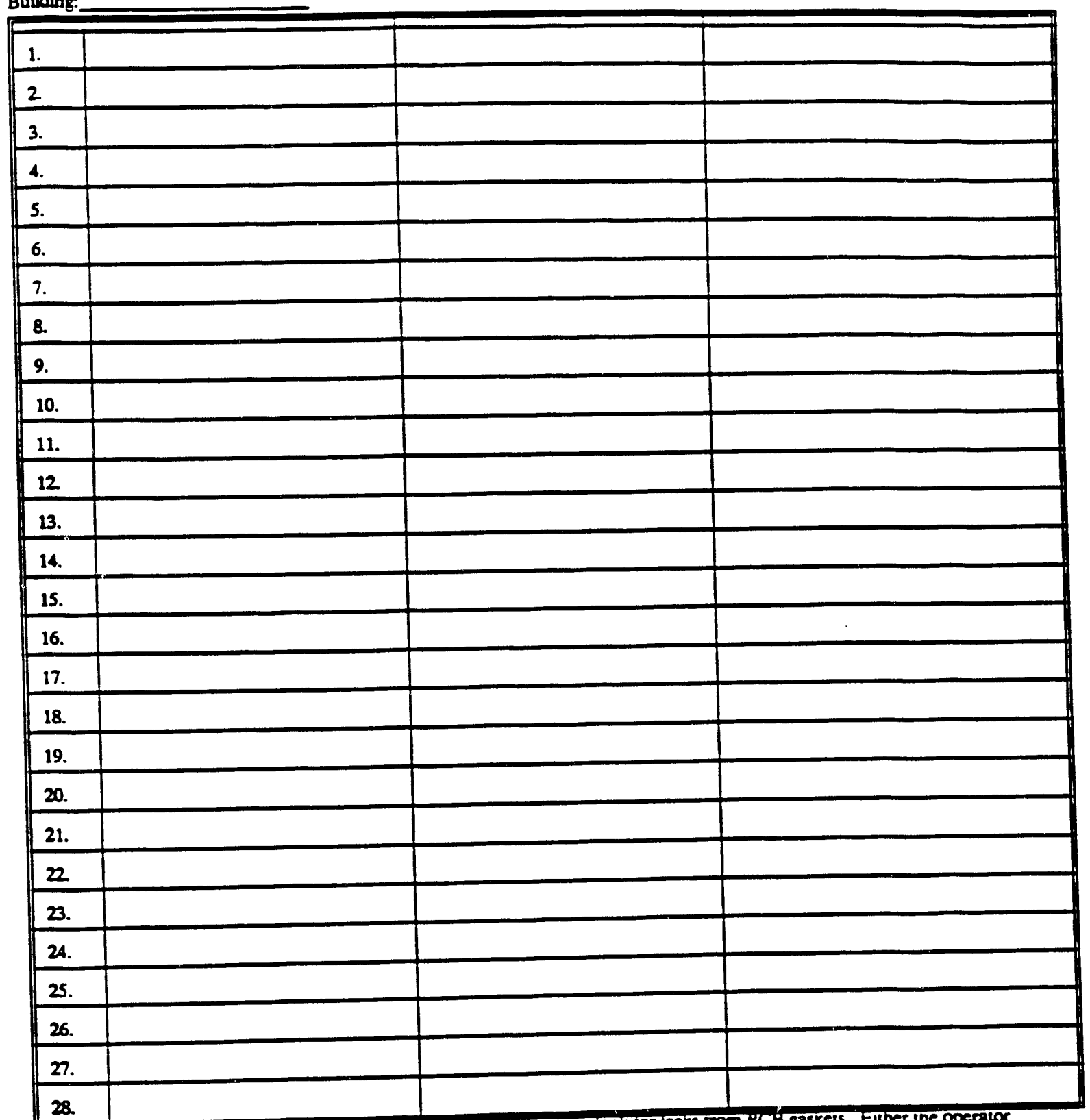

28.

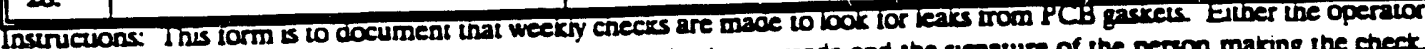

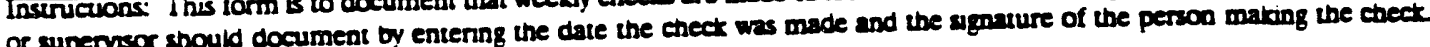

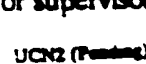

Tenap. 


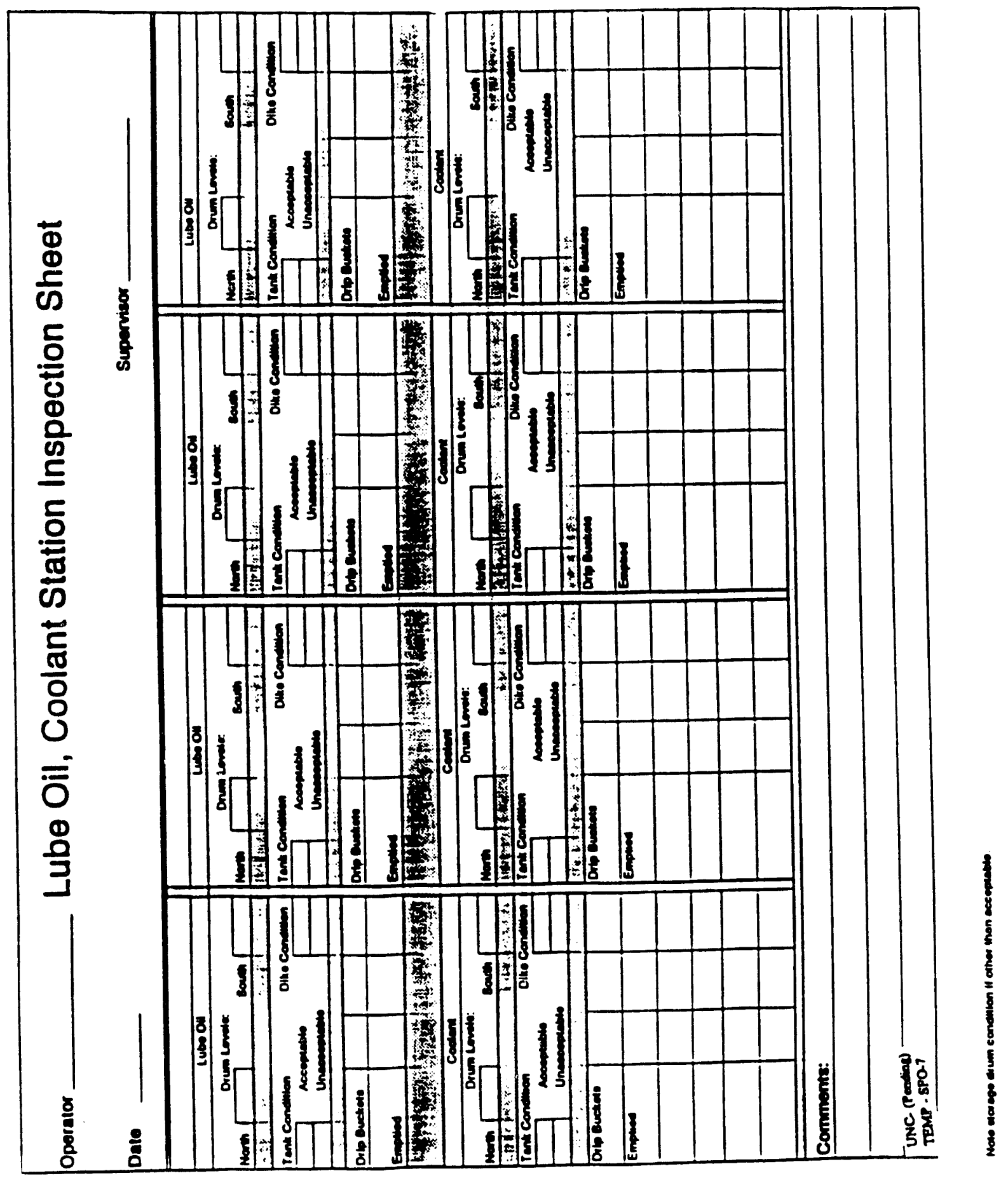




\section{SITE FACILTTY OPERATIONS}

Freon Inventory -- Building K-31

DATE:

Liquid storage drum temperature $\left({ }^{\circ} \mathrm{F}\right)$

\begin{tabular}{|c|c|c|c|c|c|}
\hline UNIT 1 & UNIT 2 & UNIT 3 & UNIT 4 & UNIT 5 & UNIT 6 \\
\hline Cell \# & Cell \# & Cell \# & Cell \# & Cell \# & Cell \# \\
\hline 1 in. & $1 \ldots$ in. & $1 \ldots$ in. & 1 in. & 1 in. & 1 in. \\
\hline 2 _ in. & 2 in. & 2 in. & ${ }^{2}{ }_{\text {in. }}$ & 2 in. & 2 in. \\
\hline 3 _ in. & 3 in. & 3 in. & 3 in. & 3 in & 3 in \\
\hline 4 in. & 4 in. & $4 \ldots$ in. & 4 in. & $4 \ldots$ in & $4 \ldots$ in. \\
\hline 5 in. & 5 - in. & 5 _ in. & 5 _ in. & 5 _ in. & 5 __ in \\
\hline 6 in. & 6 -.in. & 6 __ in. & 6 _ in. & 6 __ in. & 6 _ in. \\
\hline 7 in. & 7 -in. & 7 in. & 7 in. & 7 _ in. & 7 in. \\
\hline $8 \quad$ in. & 8 -...in. & $8 \_$in. & 8 in. & $8 \ldots$ in. & $8 \ldots$ in. \\
\hline 9 in. & 9 in. & 9 in. & 9 in. & 9 in. & 9 in. \\
\hline 10 in. & 10 in. & 10 in. & 10 in. & 10 _ in. & 10 in \\
\hline 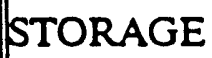 & $\mathbf{S}$ & man & \multicolumn{2}{|c|}{ in.; West Drum } & in. \\
\hline
\end{tabular}

UNC (Pendiog)

TEMP - SFO: 


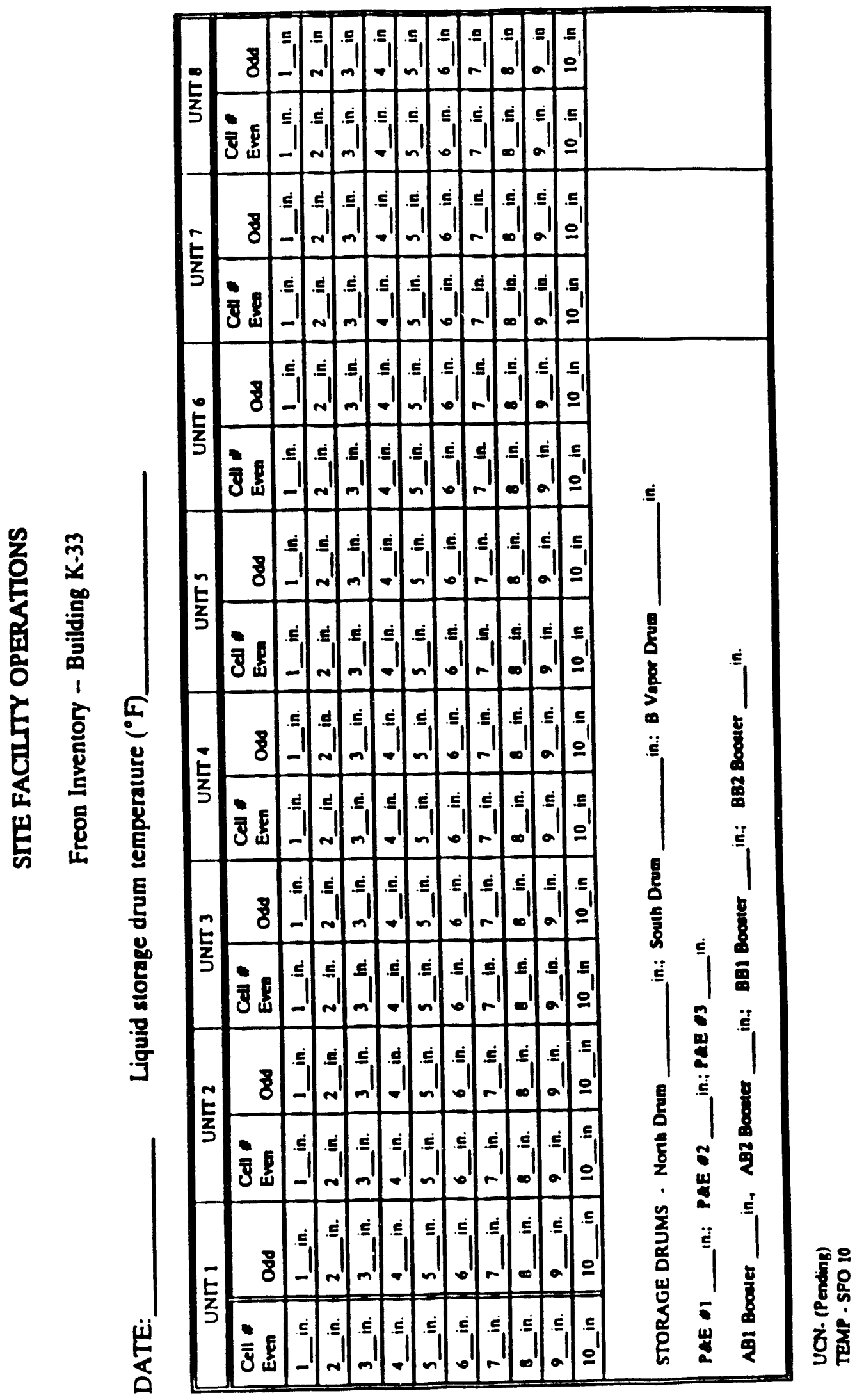




\section{GENERAL BUILDING INSPECTIONS K-}

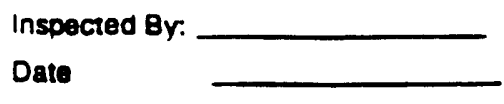

Reviowed Br:

Dato

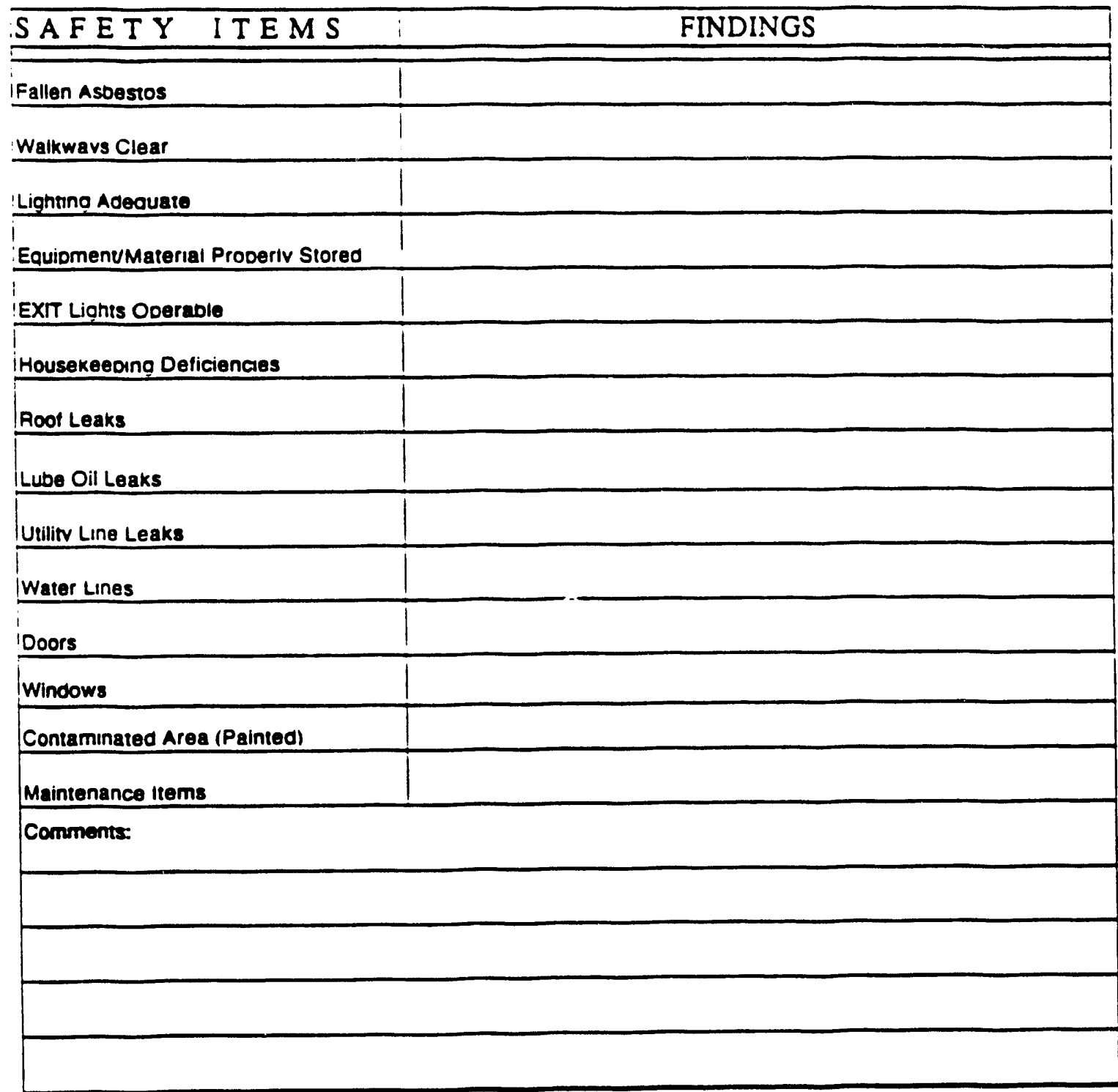

UCr. Pantine) TENP . SPO-11 


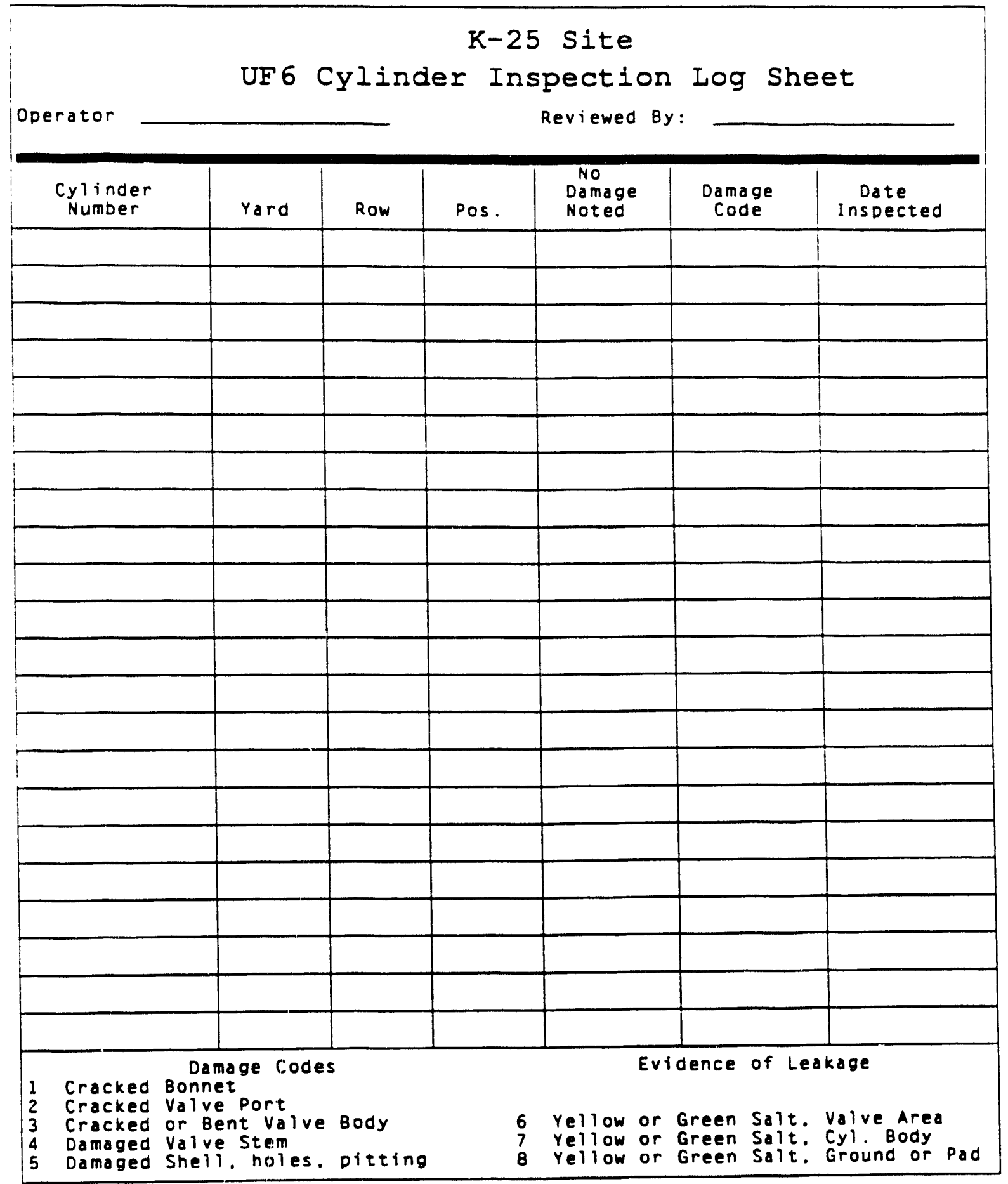


K-25 SITE ASBESTOS WALK-THROUGH INSPECTION AND ASSESSMENT FORM

Building: Room or Area:

Inspection Date:

Location(s) of Suspected Asbestos Insulation: Inside Building ( )

Outside Building ( )

Homogeneous Area(s):

Type of Insulation (Suspected Asbestos) Material:

Piping* ( ) Surfacing ( ) Tank ( ) Non-Friable ( ) Other ( )

*If piping, list the size pipe in inches and thickness of insulation

Approximate Amount of Material: Linear feet Square feet

Area Occupancy: Number of people assigned to area

$\begin{array}{llll}\text { Continuousty Occupied (daily) } & \text { ( ) } & \text { Frequently Occupied (once/week) } & \text { ( ) } \\ \text { Occasionally Occupied (Once/month) } & \text { ( ) } & \text { Unoccupied }\end{array}$

Current Condition of Insulation Material:

Percent Damage: _ \% Localized ( ) Evenly Distributed ( )

Type of Damage: Deterioration ( ) Water ( ) Physical ( ) Vibration ( )

Description:

EPA Noncompliance (visible emmissions): High ( ) Moderate ( ) Low ( )

OSHA Noncompliance (personnel exposure): High ( ) Moderate ( ) Low ( )

Overall Rating: Good ( $<1 \%$ overall damage)

Damaged ( $<10 \%$ eventy distributed or $<25 \%$ localized)

Significantly Damaged ( $>10 \%$ even or $>25 \%$ localized)

Potential for Future Disturbance:

Potential for future Physical Contact:

Potential for future Moisture Damage:

Potential for future Air Erosion:

Potential for future Vibration Damage:

Potential for future EPA/OSHA Violation:

$\begin{array}{lll}\text { High ( ) } & \text { Moderate ( ) } & \text { Low ( ) } \\ \text { High ( ) } & \text { Moderate ( ) } & \text { Low ( ) } \\ \text { High ( ) } & \text { Moderate ( ) } & \text { Low ( ) } \\ \text { High ( ) } & \text { Moderate ( ) } & \text { Low ( ) } \\ \text { High ( ) } & \text { Moderate ( ) } & \text { Low ( ) }\end{array}$

Check List:

Warning Signs Posted at Entrances

Maintenance or Repair Needed

Bulk Sampling Needed for Identification

Contaminated Material Likety to be Present
Insulation Properly Labeled Cleanup of Fallen Material Needed Area Isolated or Locked Removal Scheduled

Comments:

Inspector Signature:

Industrial Hygiene Signature:

UNC-(Pending)

TEMP - SFO-19
Date:

Date: 
B-25 Box Inventory For Building/Storage Area

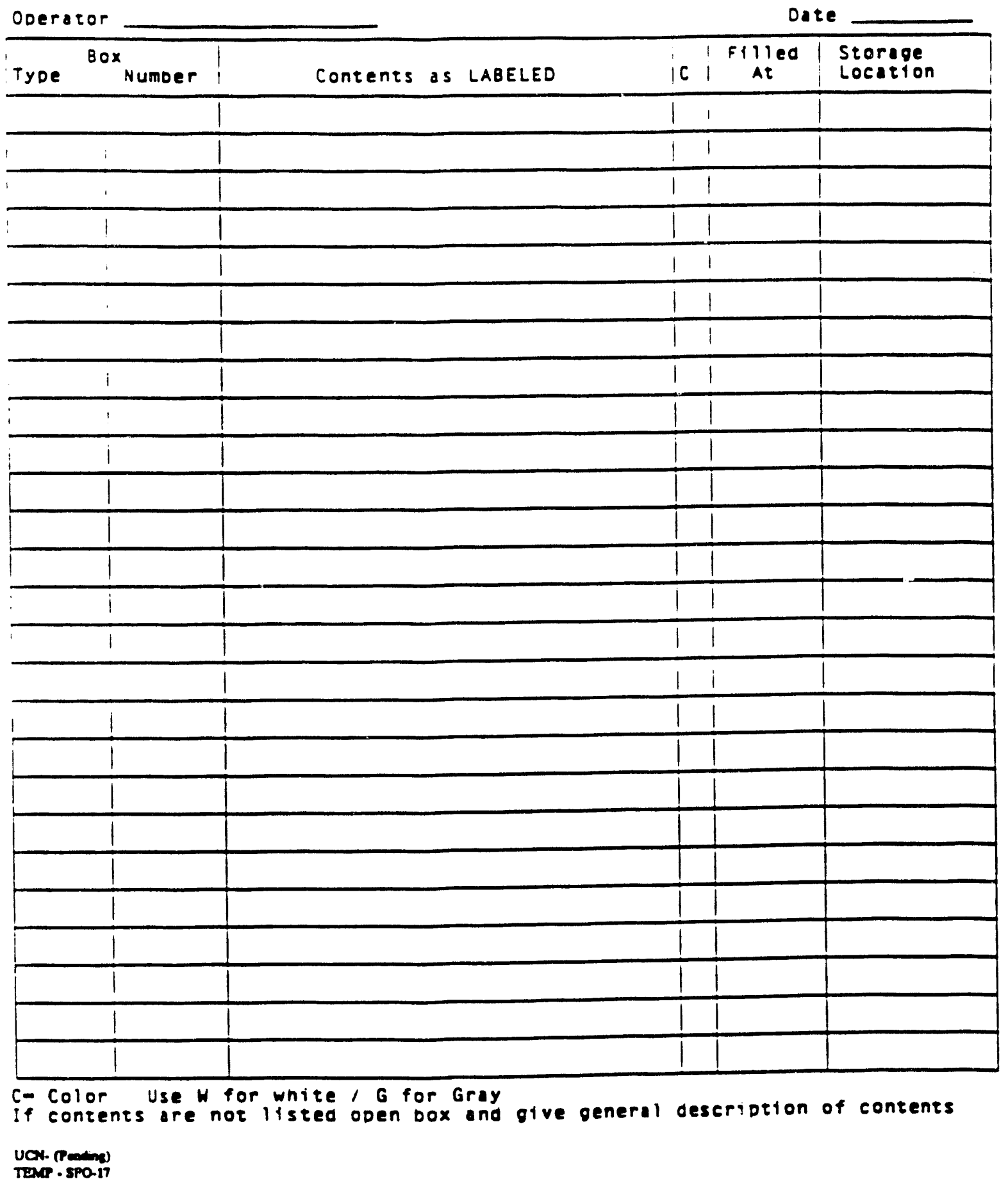


ES/ER/TM-25

\section{DISTRIBUTION}

1. J. W. Amburgey

2. L. D. Bates

3. J. S. Bogard

4. D. J. Bostock

5. T. W. Burwinkle

6. T. R. Cannon

7. O. K Clotfelter

8-12. T. K. Cothron

13. M. F. P. DeLozier

14. R. S. Eby

15. R. L. Faulkner

16. G. G. Fee

17. H. R. Gaddis

18. D. B. Gunter

19. C. E. Hall

20. L. E. Hall

21. H. E. Harper

22. S. H. Howell

23. J. M. Kennerly

24. R. K. Kibbe

25-26. A. K. Lee

27. L. W. Little
28. M. E. Mitchell

29. O. B. Morgan

30. L. E. McNeese

31. F. R. Mynatt

32. G. P. Patterson

33. F. S. Patton

34. G. A. Person

35. M. W. Rosenthal

36. T. H. Row

37. E. J. Roy

38. D. L. Smith

39. D. W. Swindle

40. A. E. Walzer

41. D. A. Waters

42. S. W. Wiley

43. H. D. Wooten

44-48. ER Document Management Center

49. Central Research Library

50. ORNL Laboratory Records

51. Y-12 Central Files

52. K-25 Site Records

53. C. Gist, DOE Oak Ridge Field Office, Post Office Box 2001, Oak Ridge, Tennessee 378318541

54-55. W. E. Murphie, Department of Energy, Office of Environmental Restoration, Eastern Area D\&D Branch, EM-423 (GTN), Washington, DC 20545

56. S. S. Perkins, DOE Oak Ridge Field Office, Post Office Box 2001, Oak Ridge, Tennessee 37831-8541

57. J. Powell, DOE Oak Ridge Field Office, Post Office Box 2001, Oak Ridge, Tennessee 378318541

58. R. C. Sleeman, DOE Oak Ridge Field Office, Post Office Box 2001, Oak Ridge, Tennessee 37831-8541

59-60. Office of Scientific and Technical Information, P.O. Box 62, Oak Ridge, TN 37831 

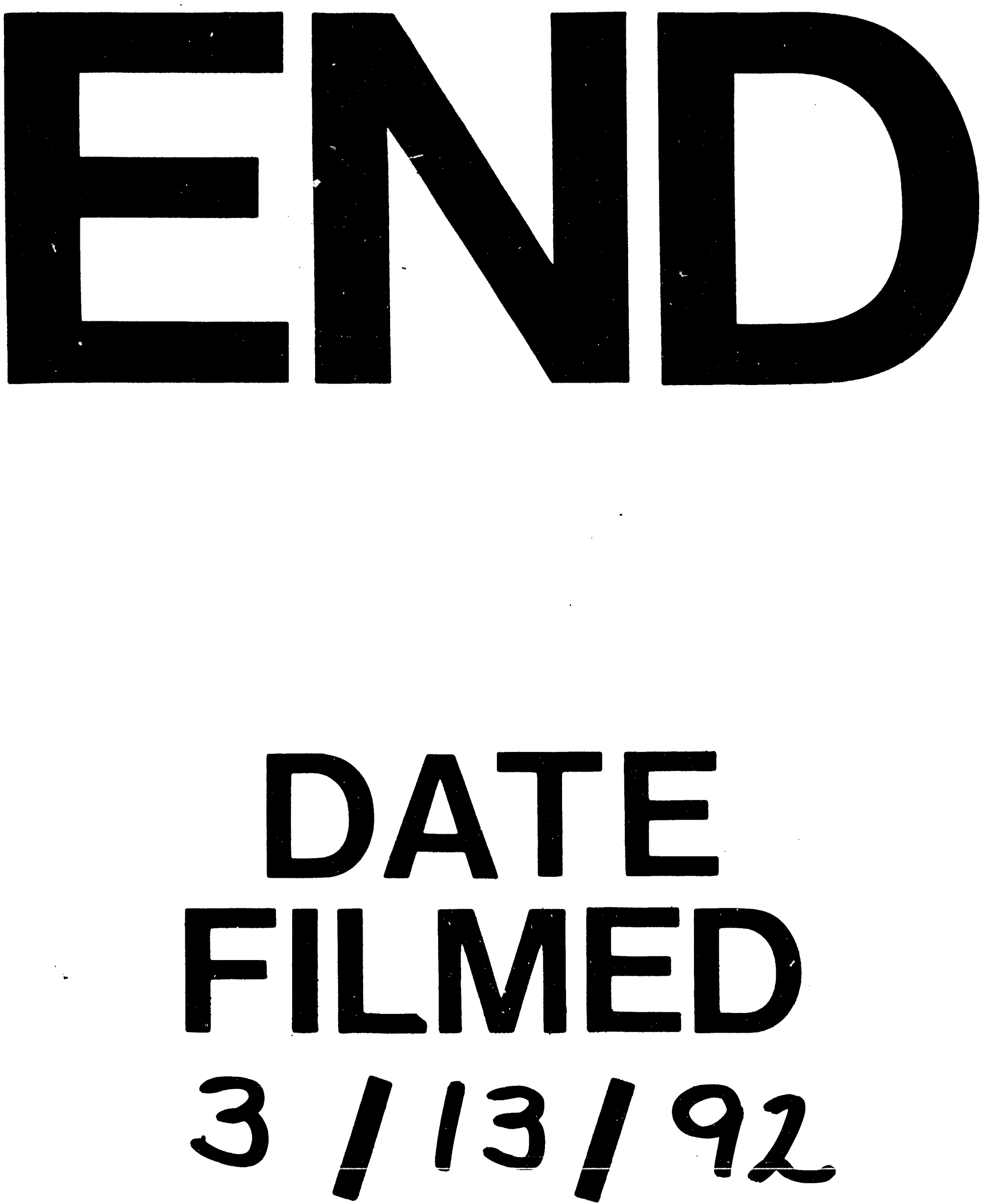
